\title{
Agroecological impact of an in vitro biotechnology approach of embryo development and seed filling in legumes
}

\author{
Sergio J. Ochatt
}

Accepted: 21 November 2014 / Published online: 30 December 2014

(C) INRA and Springer-Verlag France 2014

\begin{abstract}
Ongoing global climatic changes and growing demographic pressure have increased demand for agronomic resources and affected the agroecosystem by provoking a number of abiotic stresses that, added to biotic ones, result in physiological and metabolic disorders. Such stresses ultimately impact yield when it most needs to be improved, and understanding and resolving them is a major scientific and agronomic challenge of this century. However, many species are difficult to breed for stress resistance and improved yield for a number of reasons, ranging from a long life cycle (woody species), a reduced genetic background (most self-fertile, cleistogamous legumes) or conversely extensive heterozygosity resulting from an outbreeding nature, and also due to the mainly multigenic origin of such resistances. Biotechnologybased breeding would be an efficient alternative but, for recalcitrant crops, many attempts at in vitro regeneration met with varying degrees of success and often limited to a few genotypes, hampering exploitation of biotechnology approaches. To reduce the risk of undirected somaclonal variations amongst regenerants and transformants, it is better to produce them through somatic embryogenesis that recognises a single-cell origin but whose feasibility is also limited amongst species. There is also a need to fix the resulting genome once a novelty is obtained to ensure efficient heritability of improved traits acquired, which takes several generations in conventional breeding. Acceleration of generations through flowering and fruit set in vitro has been developed in various species including legumes. Haplo-diploidisation in vitro also offers a unique alternative to conventional methods, as it yields novel genetic combinations following doubling of haplotypes and regeneration of fertile plants
\end{abstract}

\section{S. J. Ochatt $(\bowtie)$}

INRA, UMR 1347 Agroécologie,

BP 86510, 21065 Dijon Cedex, France

e-mail: ochatt@dijon.inra.fr having gained homozygosity within a single generation. This review will examine the relationships between embryogenesis, stress and its impact on in vitro development of novel genotypes more apt for a sustainable agriculture.

Keywords In vitro plant regeneration $\cdot$ Somatic embryogenesis - Gene transfer - Abiotic and biotic stress resistance $\cdot$ In vitro selection $\cdot$ Haplo-diploidisation $\cdot$ Genetic determinism · Embryo development · Seed filling · Legumes . Medicago truncatula $\cdot$ Flow cytometry $\cdot$ Endoreduplication . Auxin

\section{Table of Contents}

1. Introduction: induced stress and embryogenesis in vitro go hand in hand

2. Legumes as a study subject

3. The model legume Medicago truncatula Gaertn

4. Seed development and the parallel with in vitro embryogenesis

5. Typical indicators of somatic embryogenesis in vitro

6. The study of seed (and embryo) filling

6.1 The central role of endoreduplication in the embryogenesis phase

6.2 The phase of morphogenesis

6.3 Auxin in embryo development, seed filling and endoreduplication

7. Functional validation of genes of interest by transformation

8. The link between cell cycle, embryogenesis and seed filling as affected by abiotic stress agents

9. Conclusion

10. References 
1 Introduction: induced stress and embryogenesis in vitro go hand in hand

Significant modifications have occurred in our planet over the last decades through an ever-increasing demographic pressure which encompassed much larger energy consumption and, in turn, is affecting the global climate (Branca et al. 2013). Demand for agronomic resources has hence substantially increased when most land apt for agriculture is already exploited and available land left is generally marginal. This has gravely affected the agroecosystem, and farmers are confronted with a number of abiotic stresses that add to those of biotic origin (e.g. pests and diseases), resulting in physiological and metabolic disorders that, ultimately, impact on yield when it most needs to be improved (Cuellar-Ortiz et al. 2008; Voisin et al. 2013; Yu et al. 2014). Therefore, understanding and resolving the impact of such stresses on yield is one of the major scientific and agronomic challenges of the twenty-first century.

In this context, a number of biotechnology-based breeding approaches offer alternatives to conventional methods to generate novel genotypes with an enhanced resistance to both biotic and abiotic stresses and coupled with an improved yield (Ochatt et al. 2010; Rai et al. 2011; Pérez-Clemente and Gómez-Cadenas 2012; Campanelli et al. 2013). In many species, applying such approaches to preexisting genotypes for in vitro selection and/or gene transfer would significantly accelerate the breeding process, which would otherwise require a large number of successive generations to fix the novel resistance traits acquired in the genome thereby ensuring their heritability in the progeny. If coupled with the in vitro acceleration of generation cycles and/or with a faster genome fixation through haplo-diploidisation, breeding could be even faster. Care should be taken, though, to avoid regenerating non-true-to-type plants due to non-controlled and spontaneous somaclonal variations, as may arise through the regeneration of plants by organogenesis from calluses or explants instead of via a single-cell origin as in somatic embryogenesis-derived regeneration.

Strategies have been developed for the induction of flowering in vitro in a number of species including legumes such as pea (Ochatt et al. 2002a, b; Ribalta et al. 2014), grasspea and barrel medic (Ochatt and Sangwan 2010) and lentil and faba bean (Mobini et al. 2014). Parallel to this, attempts have been undertaken at genetically manipulating flower induction for an increased precocity via the overexpression of genes such as Terminal Flower 1 (TFL1) gene in Arabidopsis thaliana (Hanano and Goto 2011), homologous of which have been found in many herbaceous species but also in fruit (Esumi et al. 2005, 2010; Wang and Pijut 2013) and forest tree species (Igasaki et al. 2008; Mohamed et al. 2010). On the other hand, regenerating haploid plants from unfertilised gametes followed by chromosome doubling of regenerants to yield fertile double-haploid plants would permit to achieve homozygosity in a single generation (Lülsdorf et al. 2011; Pérez-Clemente and Gómez-Cadenas 2012). However, both pathways for haploid plant production (i.e. androgenesis from microspores and gynogenesis from unfertilised ovules) depend on the possibility to induce such gametes to undergo embryogenesis.

Establishing reproducible and efficient strategies for the regeneration in vitro of fertile and true-to-type plants either issued from haplo-diploidisation as in chickpea (Grewal et al. 2009), in vitro selection for stress tolerance (Campanelli et al. 2013; Elmaghrabi et al. 2013) as in Medicago, or genetic transformation plus in vitro selection as in common bean (Kwapata et al. 2012), soybean and other legumes (Dita et al. 2006) and avoiding to a maximum the risk of undesired somaclonal variations, is a prerequisite for the exploitation of biotechnology for breeding (Ochatt et al. 2010; PérezClemente and Gómez-Cadenas 2012). However, this process encompasses several hiccups in terms of the induction of embryogenesis in vitro which is quite difficult in the socalled recalcitrant crops due, amongst other reasons, to generalised recalcitrance to regeneration, negative effects on regeneration of phenolic substances, strong genotype dependency, tendency for regeneration of hyperhydric and/or cytogenetically abnormal individuals with recovery of subfertile plants and, generally, an incomplete knowledge on the genetic determinism of the induction of embryogenesis followed by efficient germination of somatic embryos in vitro and subsequent regeneration of viable plants (Ochatt et al. 2010; Ikeuchi et al. 2013).

In recent years, various physico-chemical stress-inducing agents (osmolarity, electroporation, centrifugation, temperature shock treatments, sonication; see below) have been shown to either induce or potentiate the acquisition of regeneration competence via embryogenesis whilst simultaneously decreasing the level of responses and quality of regenerants obtained, that tended to be enfeebled, thereby leading to a paradoxical situation where stress is needed to regenerate somatic embryos capable of converting into plants but it is also detrimental to their growth. Unravelling the mechanisms underlying these enhancing effects has started for some of those agents above and is urgently needed for all of them. This, however, also requires an in-depth knowledge of the whole process of embryo development and of seed filling (Fig. 1) that precedes normal germination and the recovery of intact fertile plants from the embryos in vitro.

\section{Legumes as a study subject}

The family Leguminosae, with 650 genera and 18,000 species, is the third largest family of flowering plants and is second only to cereals in agricultural importance and 
Fig. 1 The phases of seed development and the corresponding physiological activities (adapted from Borisjuk et al. 2005)

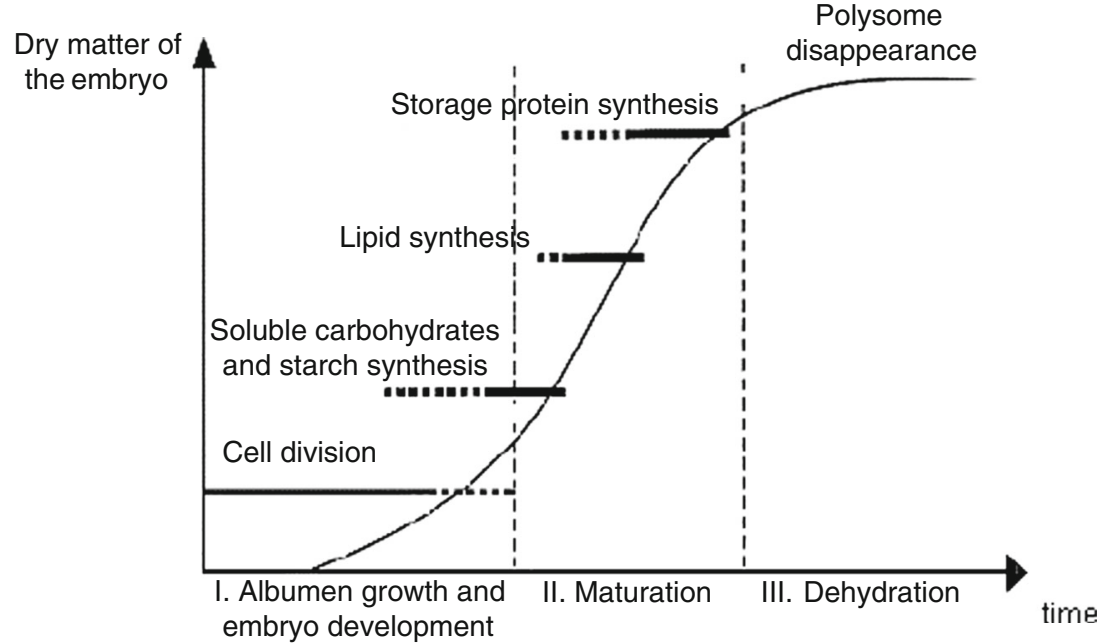

worldwide production (Journet et al. 2001; Garcia et al. 2006). Members of this family are characterised by their typical flower structure (Fig. 2), their seed anatomy and their unique ability to fix and utilise atmospheric nitrogen through a symbiotic relationship with rhizobia bacteria (Voisin et al. 2013; Yu et al. 2014). This nitrogen fixation process allows legumes to produce proteins in abundance in the absence of supplementary nitrogen fertilisation whereby they can survive even in poor nitrogen conditions (Duc et al. 1997; Hoffmann et al. 1997; Journet et al. 2001; Garcia et al. 2006; Allen et al. 2009; Patrick and Stoddard 2010; Allen and Young 2013; Atif et al. 2013a, b; Yu et al. 2014). In addition, rotation with legumes reduces energy consumption and greenhouse gas emissions, and the soil structure is enhanced by an increase in organic matter content and, consequently, an improvement of airwater relations (Branca et al. 2013; Voisin et al. 2013). In this context, Yu et al. (2014) studied rice rotations including the legume crops, broad bean (Vicia faba L.) and vetch (Astragalus sinicus L.), and clearly showed that returning the legume residues had a very positive influence not only on nitrogen transformation but also on the microenvironment, as it reduced losses due to nitrogen runoff and thereby improved the nitrogen supply capacity and resulted in an enhanced crop production coupled with a lower input of fertilisers. Furthermore, legumes can associate with endomycorrhizaforming fungi to establish symbiotic relationships, resulting in a great impact on plant nutrition through an enhanced water uptake and nutrient intake (Gianinazzi-Pearson 1996; Branca et al. 2013). In this context, a recent article by Voisin et al. (2013) has shown, using original hypernodulating pea mutants, that the number of nodules in the roots is strongly correlated with various plant parameters that are, themselves, related to the plant's carbon nutrition. On the other hand, Cuellar-Ortiz et al. (2008) have reported that in common bean (Phaseolus vulgaris L.), carbohydrate partitioning is affected by drought, its major yield constraint, and that the modulation of such partitioning towards seed filling at the early stages of pod development was a successful strategy to generate drought-resistant cultivars. The summation of these traits renders the interest in legumes very high, due to their importance in sustainable agriculture (Journet et al. 2001; Dita et al. 2006), whereby in Europe both species with seeds rich in protein and in oil are cultivated, including peas, soybeans, faba beans, lupins, chickpeas, lentils and Phaseolus beans (e.g. bush beans) as the most important ones, and with legume production in all countries of the European Union (EU) (Fig. 3). Indeed, regularly adopting legumes in a crop rotation is an important and, given the large diversity existing amongst legume crops, an easily applicable method to reduce application of chemical fertiliser whilst simultaneously also stabilising the grain yields and improving the soil quality, with a big positive impact on the health of the agro-ecosystem (Dita et al. 2006; Branca et al. 2013; Yu et al. 2014).

\section{The model legume Medicago truncatula Gaertn}

Barrel medic is an annual autogamous diploid $(2 n=16)$ legume species native in the Mediterranean basin, where it occurs in open areas in typical ephemeral populations (Barker et al. 1990; Blondon et al. 1994; Rose 2008). The pods of $M$. truncatula are abundantly set in the absence of insect pollination and contain up to 12 seeds, where basal seeds develop faster than distal ones (Journet et al. 2001; Gallardo et al. 2006a, b; Ochatt 2011; Atif et al. 2013a, b). Mature pods are compact spiky coils, which remain indehiscent (Garcia et al. 2006; Gallardo et al. 2006a, b; Ochatt 2011). Besides its use as a forage crop, $M$. truncatula is phylogenetically close to the widely cultivated legumes pea and faba bean (Bataillon and Ronfort 2006), and closely related to alfalfa, Medicago sativa, which is a tetraploid, outcrossing species with low selffertility (Barker et al. 1990). In addition, barrel medic is 
Fig. 2 Some examples showing the biodiversity amongst plants and flowers of legume crops: a Pisum fulvum Vavilov D265, b P. sativum L. (pea) cv. Térèse (a, b courtesy of C. Delaitre, INRA Dijon); c, d Vicia faba L. (faba bean; courtesy of B. Raffiot, INRA Dijon): c close-up of flower, $\mathbf{d}$ different genotypes in the field
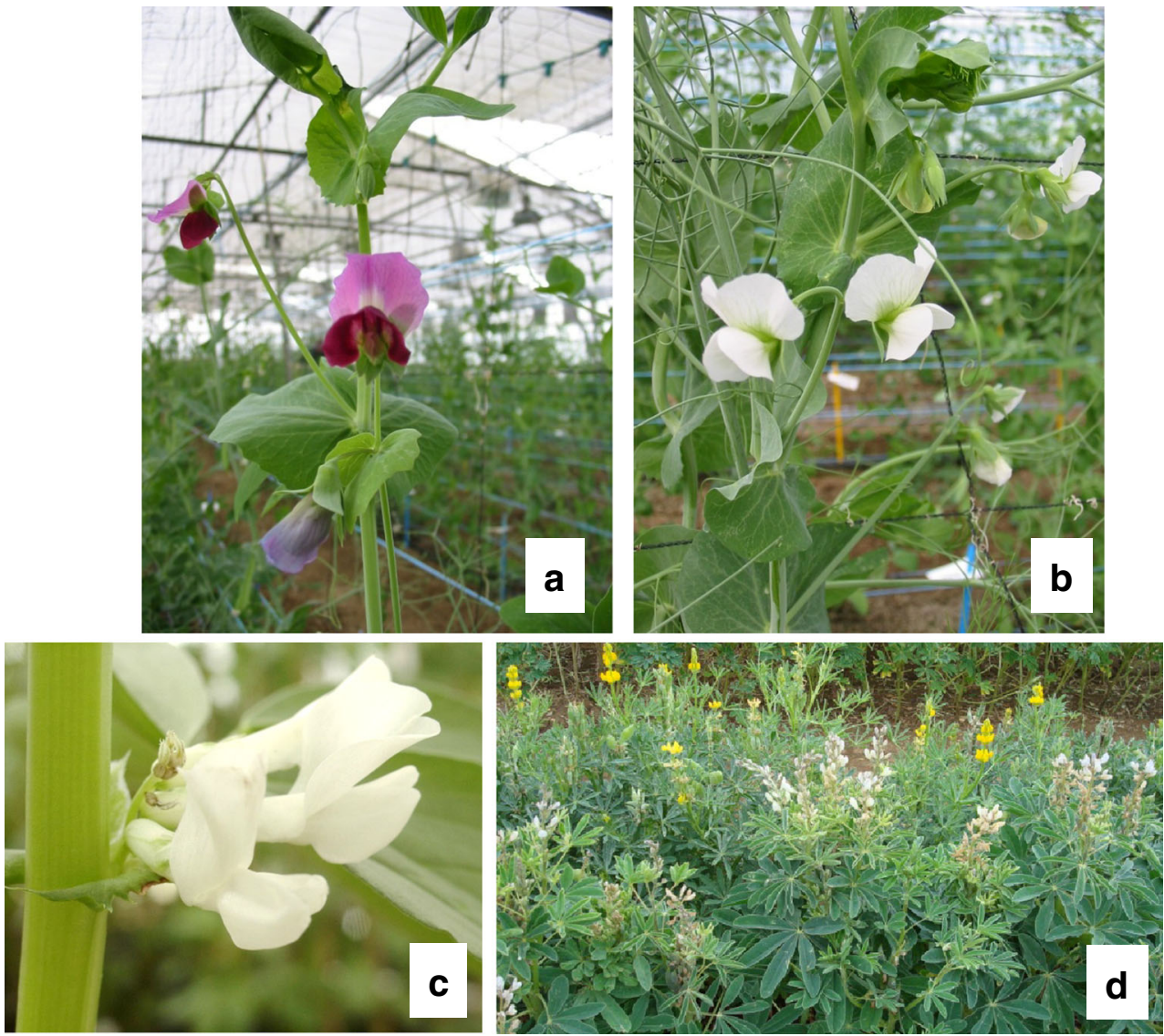

suitable for fundamental studies due to its small genome size (500 Mb/1 C), short generation time and transformation and regeneration efficiency, that are rare amongst annual legumes (Barker et al. 1990; Trinh et al. 1998; Rose 2008; Ochatt et al. 2013). Moreover, interactions of plants with symbionts, i.e. Sinorhizobium meliloti and Glomus spp., pests and pathogens can be investigated (Gallardo et al. 2006a, b; Rose 2008; Parádi et al. 2010; Ochatt 2011).

Seed development and storage protein accumulation follow a similar pattern as in the major grain legumes, and its use for genomic studies of seed development and for analysis of seed filling in grain legumes is fully adequate (Gallardo et al. 2006a, b; Rose 2008; Ochatt 2011; Atif et al. 2013a, b). Mature seeds of $M$. truncatula consist mainly of the embryo and of a persistent endosperm of up to $10 \%$ of the final seed mass, whereas mature seeds of pea or faba bean comprise mainly the embryo (Ochatt 2011; Gallardo et al. 2006a, b; Verdier et al. 2013). In addition, the protein content of the seeds of $M$. truncatula accounts between 35 and $45 \%$ and most carbon is stored in the form of oil with a starch content of
Fig. 3 Grain legume production in the EU countries (FAO 2012)

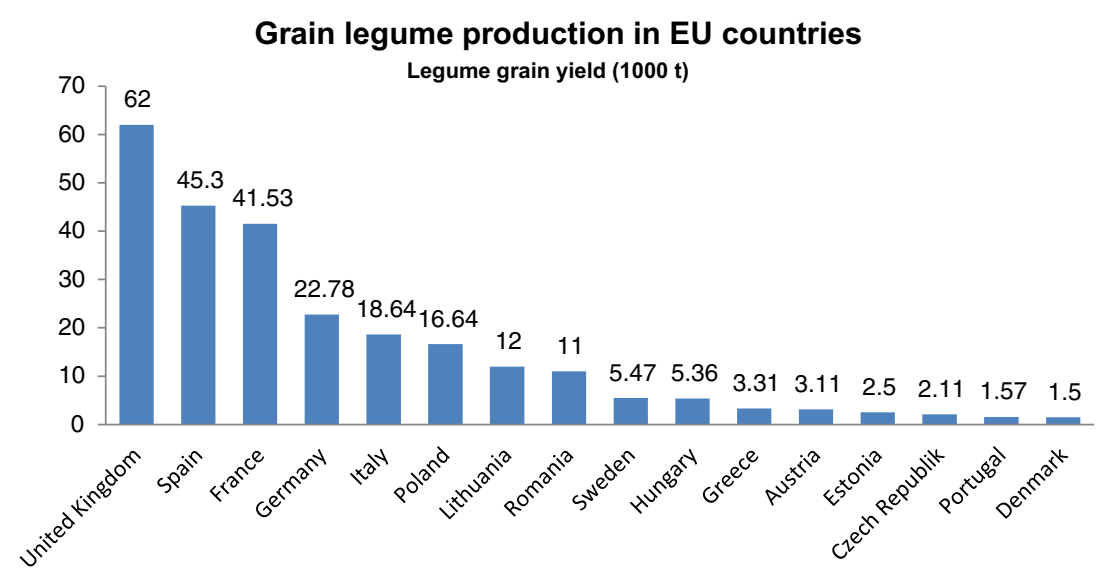

Most producing countries in Europe 
less than $1 \%$ (Gallardo et al. 2003, 2006a, b; Thompson et al. 2009), whilst pea or faba bean store starch as the principal form of carbon. Thus, the resemblance to legume oilseeds as soybean is significant (Jones et al. 2010; Allen and Young 2013), wherefore barrel medic can also serve as a model for soybean or other economically important legume species (Barker et al. 1990; Gallardo et al. 2003; Aghamirzaie et al. 2013).

\section{Seed development and the parallel with in vitro embryogenesis}

Seed development is an important process, by which quantity and quality of different food reserves within the seed are determined (Gallardo et al. 2003, 2006a, b; Allen et al. 2009; Jones et al. 2010; Patrick and Stoddard 2010; Aghamirzaie et al. 2013; Allen and Young 2013; Verdier et al. 2013). The seeds comprise three distinct components, i.e. the embryo, which gives the daughter plant; the endosperm that transmits nutrients from the maternal tissues to the embryo during embryogenesis and maturation; and the seed coat, which protects the other tissues and modifies and controls the nutrient supply to the embryo (Weber et al. 2005; Le et al. 2007; Thompson et al. 2009; Ochatt 2011; Atif et al. 2013a, b; Verdier et al. 2013; Abirached-Darmency and
Ochatt 2013). Compared to monocots, the endosperm in most dicots is only transient and successively replaced by the growing embryo, wherefore the final seed size is primarily determined by the cotyledon cell number and size (Abirached-Darmency et al. 2005; Ochatt 2011; Atif et al. 2013a, b; Verdier et al. 2013; Abirached-Darmency and Ochatt 2013).

Amongst legume seeds, seed development after the double fertilisation follows a similar pattern and can be divided into three key phases: cell division, seed filling and the phase of dehydration and acquisition of desiccation tolerance (Weber et al. 2005; Gallardo et al. 2006a, b; Le et al. 2007; Ochatt 2011; Figs. 1 and 4) characterised by distinct physiological events and activities. Recent studies have shown that the transition between phases in developing seeds is mainly regulated at the transcriptional level in legumes (Le et al. 2007) including soybean (Jones et al. 2010; Aghamirzaie et al. 2013), faba bean (Patrick and Stoddard 2010) and M. truncatula (Atif 2012; Atif et al. 2013a, b; Noguero et al. 2013; Verdier et al. 2013).

Embryogenesis, the first phase of seed development, is characterised by the differentiation of the embryo through several distinct stages (globular, heart and torpedo), ending at the cotyledon stage (Gallardo et al. 2003; Verdier et al. 2008), which are identical to those observed for somatic embryos (Ochatt et al. 2010, 2013) (Fig. 5).
Fig. 4 The various phases of embryo growth and seed development in M. truncatula
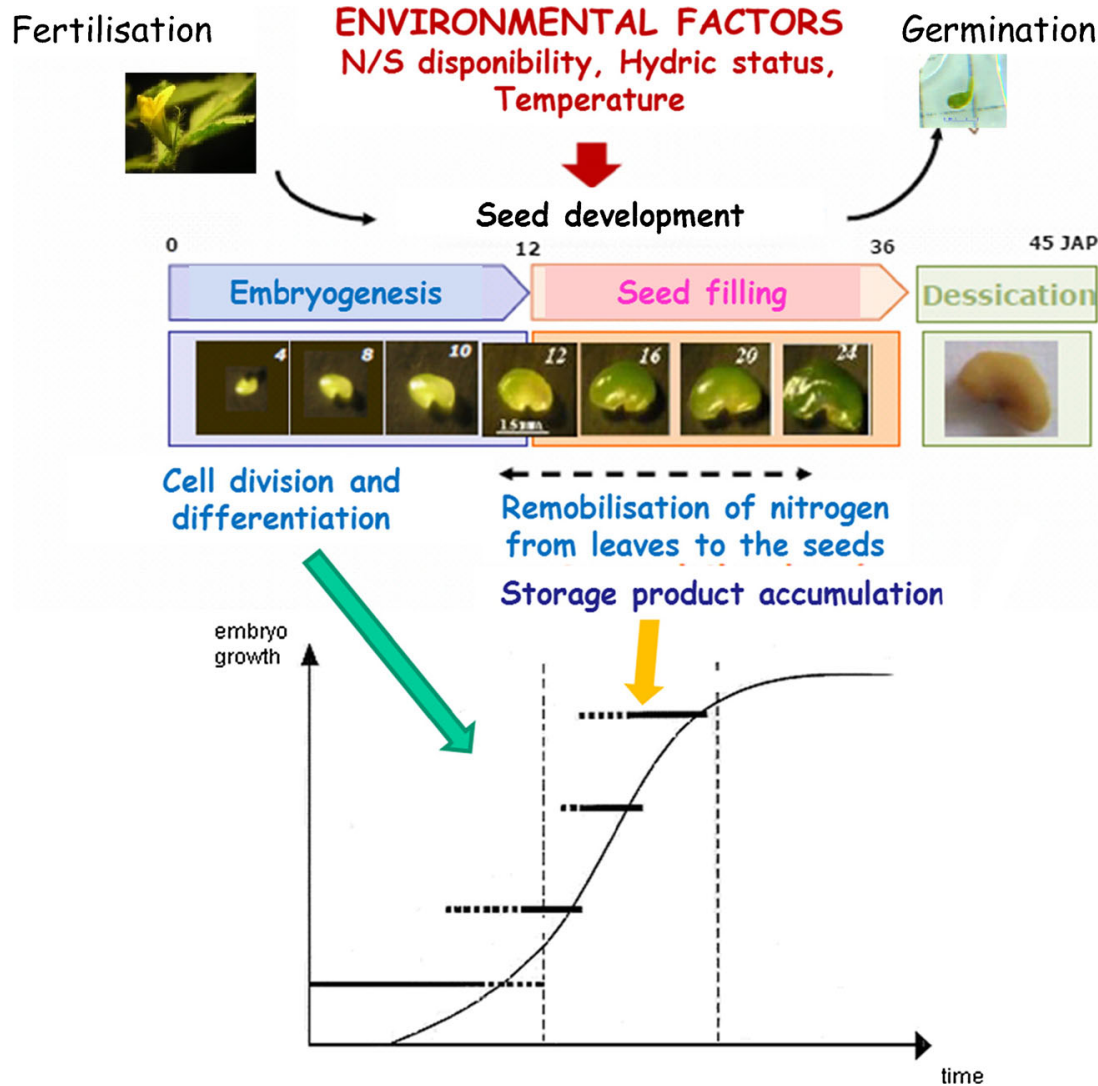

45 JAP 


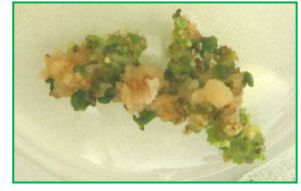

Embryogenic callus

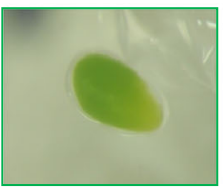

Globular

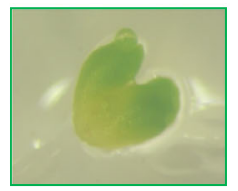

Heart

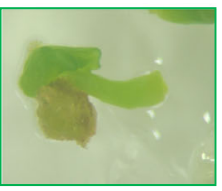

Torpedo

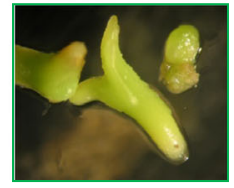

Cotyledonary

Fig. 5 The sequence of developmental stages from an embryogenic callus to a mature somatic embryo at the cotyledonary stage in M. truncatula

During this morphogenesis phase, the embryo grows mainly by cell division, directed by the maternal seed coat, which modifies and controls the nutrient supply to the embryo (Weber et al. 2005; Gallardo et al. 2006a, b; Ochatt 2011; Abirached-Darmency and Ochatt 2013; Allen and Young 2013; Atif et al. 2013a, b; Verdier et al. 2013; Voisin et al. 2013). In this regard, this phase is crucial for the final seed size and weight, determined by the number of cotyledonary cells as shown in faba bean (Patrick and Stoddard 2010) and by the maximum size they can reach (Ochatt 2011; Atif et al. 2013a, b; Verdier et al. 2013). In seeds of the model legume M. truncatula (Fig. 4), the embryogenesis lasts approximately 12 days after pollination (DAP), whereby the cell division begins to cease from 6 to 8 DAP onwards (Gallardo et al. 2003; Verdier et al. 2008, 2013; Abirached-Darmency et al. 2005; Ochatt 2011; Atif et al. 2013a, b; AbirachedDarmency and Ochatt 2013). Moreover, the water content of seeds remains continuously high $(\sim 90 \%)$ and seeds are unable to germinate or withstand desiccation (Weber et al. 2005; Gallardo et al. 2006a, b; Ochatt 2011). On the other hand, Patrick and Stoddard (2010) showed that in faba bean, the expansion of cotyledonary cells haults once the mechanical barriers represented by the seed coat and space inside the cavity of the pod are met. The same phenomenon was also verified in common bean (Cuellar-Ortiz et al. 2008) and in many studies with developing seeds of soybean (Allen and Young 2013 and references therein).

The second phase of seed development corresponds to seed filling and maturation and is characterised by the accumulation of storage proteins, the acquisition of germination ability and desiccation tolerance (Fig. 4; Gallardo et al. 2006a, b; Verdier and Thompson 2008; Allen et al. 2009; Ochatt 2011; Allen and Young 2013; Verdier et al. 2013). During the transition from embryogenesis to this developmental phase (12-14 DAP), cell divisions cease and the embryo develops from a meristem-like tissue into a highly differentiated storage organ (Weber et al. 2005; Atif et al. 2013a, b). Furthermore, the transition phase is associated with the gain of photosynthetic activity of the embryo as shown in soybean (Allen et al. 2009), the induction of storage-associated gene expression (Weber et al. 2005; Gallardo et al. 2006a, b) and the onset of endoreduplication (Ochatt 2008, 2011; Atif et al. 2013a, b). In terms of legume storage protein accumulation from 14 up to 20 DAP, the major protein classes, i.e. vicilin, legumin and convicilin, accumulate in a sequential fashion, starting with vicilins at 14 DAP, followed by the legumins at $16 \mathrm{DAP}$ and, at $18 \mathrm{DAP}$, the convicilins (Gallardo et al. 2003, 2006a, b; Verdier et al. 2008). During this accumulation process, the embryonic cells continue growing by enlargement (Ochatt 2011), the seed dry weight increases and the relative water content decreases (Gallardo et al. 2003; Gallardo et al. 2006a, b; Allen et al. 2009; Jones et al. 2010). Furthermore, the seeds gain the ability to germinate at approximately $14 \mathrm{DAP}$ and acquire desiccation tolerance 2 to 3 days later (16-19 DAP) (Gallardo et al. 2003, 2006a, b; Ochatt 2011). Unlike cereals, the protein content in legume seeds ranges from 20 up to $40 \%$, whereas the economical and nutritional significant storage compounds consist principally of the legumin (11S) and vicilin (7S) globulin classes (Gallardo et al. 2003; Verdier et al. 2008) that accumulate during the seed filling phase of seed development and are mainly stored in the cotyledonary cells of the embryo (Golombek et al. 2001; Gallardo et al. 2006a, b, 2008; Ochatt 2011). There is, thus, great interest in evaluating the mechanisms that control storage protein accumulation and protein content, and much research effort has aimed at improving seed quality (Golombek et al. 2001; Gallardo et al. 2003, 2006a, b; Le et al. 2007; Verdier and Thompson 2008; Jones et al. 2010; Patrick and Stoddard 2010; Allen and Young 2013).

The dehydration phase of development starts between 20 and 24 DAP and is characterised by a great decrease in water content, during which the seed dry weight remains constant. Moreover, the embryo becomes inactive and may undergo dormancy, and at 36 DAP (Fig. 4), the development of the M. truncatula seed is finished (Gallardo et al. 2003; Ochatt 2011; Atif et al. 2013a, b).

During somatic embryogenesis induced in vitro, embryos follow a developmental trend that also takes them from the globular to the heart to the torpedo and finally to the cotyledonary stage, at which somatic embryos are capable of germinating to give a complete viable plant (Fig. 5; Ochatt et al. 2010, 2013). However, in recalcitrant species, this process tends to stop at two crucial steps, i.e. early on following the formation of somatic embryos at the globular stage and in the transition from the torpedo to the cotyledonary stage, with embryos where (instead of growing, gaining weight and ultimately germinating) the accumulation of storage compounds is arrested and the embryos gradually wither in time with their ultimate death.

Positive effectors of regeneration are described in the literature that, when overexpressed, promote callus formation, 
somatic embryogenesis or organogenesis (reviewed in Ikeuchi et al. 2013). However, reports in multiple species show that the constitutive expression of such effectors is generally not compatible with the eventual recovery of true-to-type fertile adults. Conversely, various physico-chemical (pre-)treatments of donor plants and gametes have been shown to significantly improve the androgenetic responses, particularly in legume crops (Grewal et al. 2009; Ochatt et al. 2009; Lülsdorf et al. 2011; Ochatt 2013a, b), but also in a range of other species including woody and herbaceous ones (Ochatt 2013a, b). However, the mechanism(s) through which this elicitation and/or potentiation of the androgenic potential occurs are often still being elucidated.

\section{Typical indicators of somatic embryogenesis in vitro}

The study of in situ embryogenesis in plants is complex because the embryo is embedded in the endosperm and covered by ovule tissues that will give rise to the seed integument (Ochatt 2011). The embryo is thereby difficult of access and not adapted to dissection of tissues as needed for biochemical studies. Somatic embryogenesis from differentiated organs (Ochatt et al. 2008, 2013) provides an alternate experimental system for research of the cellular and molecular bases of embryogenesis, the latter being not yet fully well-known (Mordhorst et al. 1997; Gutierrez et al. 2007). Transition from the dedifferentiated to the embryogenic status is complex and includes several phases (dedifferentiation, reactivation/cell division) and a large metabolic and developmental reprogramming (Fehér et al. 2003; Le et al. 2007). On the other hand, endoreduplication strongly affects all developmental phases (Ochatt 2008, 2011), being strongly correlated with the ability to regenerate from protoplasts in pea (Ochatt et al. 2000a, b), as from cell suspensions and callus in M. truncatula (Elmaghrabi and Ochatt 2006). It also acts on the number of tissue layers formed during organogenesis (Ochatt 2008; Ochatt et al. 2002a, b) and on the acquisition of tolerance to abiotic stress (Elmaghrabi et al. 2013) in legumes. Other indicators of embryogenic competence (intracellular and medium osmolarity, cell surface, cell wall thickness) have also been identified in cell cultures of legumes (Ochatt et al. 2008). The expression kinetics of certain genes involved in morphogenesis in vivo with cell cultures was recently examined of $A$. thaliana, whereby WUSCHEL, $S E R K 1, Z L L, S R 1$ or STM seemed to play a major role in the acquisition of competence for regeneration in vitro (Duclercq et al. 2011). In this respect, WUSCHEL was shown to be particularly involved in the very early stages of embryo development, from anthesis to 6 DAP (Zuo et al. 2002 Kurdyukov et al. 2014), whilst seed-specific expression of AINTEGUMENTA during the later stages of development led to the production of larger seeds of a better germination ability at maturity (Confalonieri et al. 2014). On the other hand, expression of SERK1, WEE1, PC5S and CCS52 significantly augmented in $M$. truncatula salt-resistant calli at precisely the $\mathrm{NaCl}$ concentration where homeostasis between $\mathrm{Na}^{+}$and $\mathrm{K}^{+}$and, hence, tolerance to salt stress was evident and concomitant with good embryogenic capacity (Elmaghrabi et al. 2013). Finally, long-time research on the effects of electroporation on growth and regeneration has demonstrated that electric shocks increase DNA synthesis and improve both traits, although the genetic determinism of its way of action is still to be elucidated (Ochatt 2013a, b). Thus, SERK1, WEE 1 and CCS52, plus WUSCHEL, are likely good candidate genes for unravelling acquisition of regeneration competence in legumes and they are also amongst the genes that would be interesting to study within the context of acquisition of salt tolerance through the transformation of M. truncatula (Ochatt et al. 2013) and crop legumes. Indeed, the inconvenience of dealing with biotechnology-derived plants may be acceptance by consumers in Europe, but the situation in this respect seems to be changing, as indicated by a number of recent publications (Peng 2011; Christou 2013; Potrykus 2013), showing that an increasing number of EU countries are adopting policies in line with those applied elsewhere in the world that permit assays of genetically modified organism (GMO) crops and their field culture. In any case, DH or in vitro selected mutants and soma(proto)clonal variants are not amongst the biotechnology-based plants classified as GMOs and remain therefore an appealing alternative for the generation of new, stress-resistant genotypes.

\section{The study of seed (and embryo) filling}

Following the double fecundation in the embryo sac, seed/embryo morphogenesis starts by multiple cell divisions followed by differentiation (Wiese et al. 2004; Rahmani et al. 2009; Verdier et al. 2013; Abirached-Darmency and Ochatt 2013). This first phase is intimately associated with the synthesis of soluble carbohydrates and of starch (Baud et al. 2002, 2005), whilst during the second developmental phase, of maturation, the dry weight of seeds/embryos increases and all storage products accumulate in the expanding cells (Weber et al. 1998; Gallardo et al. 2006a, b; Ochatt 2011; Atif et al. 2013a, b). During the last phase, which includes the end of maturation and dehydration, the dry weight of the seeds remains constant, whilst they lose much water and the embryo thus becomes metabolically quiescent (Gutierrez et al. 2007; West and Harada 1993). The duration of the phase of embryogenesis is hence essential in the determination of the potential of accumulation of storage products by seeds and embryos, through the number of cotyledonary cells that are formed, and of their maximum size (surface and volume) (Munier-Jolain and Ney 1998; Patrick and Stoddard 2010; Atif et al. 2013a, b; 
Ochatt 2013a, b). In this respect, the speed of the seed/embryo growth mainly depends on the number of cotyledonary cells formed, which is not very sensitive to the climatic culture conditions for growth during filling (Munier-Jolain and Ney 1998; Ochatt et al. 2008). Moreover, the differences in size between genotypes with small and large seeds are most often highly correlated with differences of growth speed and thus also with the number of cotyledonary cells they included (Lemontey et al. 2000; Munier-Jolain and Ney 1998; Patrick and Stoddard 2010; Ochatt 2011, 2013a, b), whereby they are also correlated with the trophic (Gallardo et al. 2006a, b; Ochatt 2011; Atif et al. 2013a, b) and physical (Cuellar-Ortiz et al. 2008; Ochatt 2013a, b) environment of the embryo. The arrest of seed/embryo filling occurs when the resources available for their growth are exhausted (Gallardo et al. 2006a, b; Ochatt 2011) and/or when the maximum seed size is attained (Ochatt 2006, 2008, 2013a, b; Patrick and Stoddard 2010; Allen and Young 2013). Interestingly, this maximum size depends (i) on the number of cotyledonary seeds (Ochatt et al. 2008; Ochatt 2013a, b) and (ii) on the maximum cell volume (Ochatt et al. 2008; Ochatt and Moessner 2010; Ochatt 2013a, b), which are both under simultaneous genetic (Lemontey et al. 2000; Ochatt 2013a, b) and environmental (Ochatt 2013a, b; Atif et al. 2013a, b) determinism. With respect to the potential of storage product accumulation, a modification in the availability of assimilates to the growing seed/embryo plays a paramount role, notably with respect to nitrogen (Gallardo et al. 2006a, b; Jones et al. 2010; Allen and Young 2013) and sulphur (Zuber et al. 2010; Ochatt 2011; Rajjou et al. 2012).

\subsection{The central role of endoreduplication} in the embryogenesis phase

The embryogenesis phase is crucial for the potential of storage product accumulation through the number of cotyledonary cells that are formed. During transition to the storage product accumulation phase, cotyledonary cells expand and they start to synthesise storage proteins and starch and, most interestingly, undergo endopolyploidisation, as shown for faba bean (Patrick and Stoddard 2010) and M. truncatula (Ochatt 2008, 2011). In this respect, the thin-walled parenchyma cells in the seed coat differentiate into transfer cells (AbirachedDarmency et al. 2005), and the resulting increased plasma membrane area is correlated with an increased nutrient flow to the rapidly growing embryo (Jones et al. 2010; Patrick and Stoddard 2010). In turn, measurement by flow cytometry of the mitotic index (Ochatt 2008) and of the onset of endoreduplication also becomes essential for the study of embryogenesis (Atif et al. 2013a, b; Ochatt 2006, 2008, 2011; Abirached-Darmency and Ochatt 2013).

A classical cell cycle comprises of four distinct phases (G1, $\mathrm{S}, \mathrm{G} 2, \mathrm{M})$ and it involves the accurate duplication and segregation of chromosomes, leading to the transmission of the genetic information from one mother cell to two daughter cells (Grafi 1998; Joubès and Chevalier 2000; Doležel et al. 2007; Ochatt 2008; Atif et al. 2013a, b). In contrast, endoreduplication is a modified cell cycle, characterised by one or several rounds of DNA replication in the absence of mitosis (karyokinesis and cytokinesis). Given that during every round of endocycles the relative nuclear DNA content doubles, the DNA ploidy level increases (Grafi 1998; Joubès and Chevalier 2000; Joubès et al. 1999; Doležel et al. 2007; Ochatt 2008), e.g. up to $128 \mathrm{C}$ in M. truncatula (Ochatt 2006, 2011; Atif et al. 2013a, b) and even higher in pea (Lemontey et al. 2000).

The G1 phase of the cell cycle is a checkpoint that ensures the availability of adequate material to pursue the cycle to the $\mathrm{S}$ phase, a step of accurate replication of DNA (Doležel et al. 2007). Once DNA replication has taken place, DNA duplication is controlled during the $\mathrm{G} 2$ phase which leads to the final mitosis (M) phase, where the duplicated chromosomes segregate and cell division proceeds (Grafi 1998; Joubès and Chevalier 2000; Ochatt 2008).

Endoreduplication is the most common mode of polyploidisation in plants, and it has been reported to occur in a wide range of cell and tissue types, including seeds (endosperm and embryo suspensor) (Lur and Setter 1993; Lemontey et al. 2000; Ochatt 2008, 2011; Atif et al. 2013a, b; Wirsich et al. 2013, Abirached-Darmency and Ochatt 2013), trichomes (Traas et al. 1998; Joubès and Chevalier 2000) and fruits (Joubès and Chevalier 2000; Ochatt 2008), being ubiquitous in $(>90 \%)$ the angiosperms (Joubès and Chevalier 2000; Doležel et al. 2007). The process is still poorly understood (Doležel et al. 2007), but it has been shown that plant cells often transit into endocycles at well-defined time points during plant development, thereby indicating a likely developmental regulation (Joubès and Chevalier 2000; Joubès et al. 1999; Ochatt 2008; Ishida et al. 2009).

In this context, immature seeds of the model legume M. truncatula undergo endocycles from 8 to $10 \mathrm{DAP}$ onwards, up to 18-20 DAP, and endoreduplication thus becomes a cytogenetic imprint marking the initiation of cell differentiation as well as the onset of the accumulation of storage proteins (Rose 2008; Ochatt 2006, 2008, 2011; Atif et al. 2013a, b; Wirsich et al. 2013; Abirached-Darmency and Ochatt 2013). Furthermore, cell volume within a range of tissues from different species has also been correlated with the extent of nuclear endoreduplication (Lemontey et al. 2000; Hao et al. 2002; Ochatt 2008), so it might provide a mechanism whereby cells increase the availability of DNA template combined with a greater level of gene expression (Grafi 1998; Joubès and Chevalier 2000; Ishida et al. 2009; Atif et al. 2013a, b; Abirached-Darmency and Ochatt 2013). Controlling endoreduplication is hence of great interest, particularly in plants with a small genome, as this alternative to a normal cell cycle is a means of increasing genetic and 
metabolic capacities (Ochatt 2008). Regarding the control of the switch from mitotic cycles to endocycles, diverse components are involved, including molecular factors such as cyclindependent kinases (CDKs), which are involved in the progression of mitotic cycles, or phytohormones, e.g. auxins (Joubès and Chevalier 2000; Joubès et al. 1999; Ishida et al. 2009; Atif et al. 2013a, b; Wirsich et al. 2013), but their respective roles are as yet not well defined.

In terms of seed development, the number of cotyledonary cells formed by a developing seed depends on:

- The mitotic activity: Under the effect of the maternal environment (Lemontey et al. 2000; Gutierrez et al. 2007; Ochatt 2011), it needs the study within the embryo of (i) the relationship between the composition of the apoplastic liquid and the mitotic activity whilst also taking into consideration the genetic variability (Gutierrez et al. 2007; Ochatt 2013a, b); (ii) the relationship between the composition of the apoplastic liquid and the composition of the sap flow reaching the pods; and (iii) the direct effect of the physical environment on the mitotic activity (Ochatt 2008, 2011, 2013a, b; Jones et al. 2010; Allen and Young 2013) and its interactions with both the composition of the apoplastic liquid and of the embryo's genome (Atif et al. 2013a, b; Gallardo et al. 2006a, b; Ochatt 2008, 2011; Ochatt et al. 2008; Wirsich et al. 2013).

- The duration of embryogenesis: This is also under the control of the embryo's genome (Gutierrez et al. 2007; Lemontey et al. 2000; Ochatt 2011), but the effects of its interaction with the environment are not yet well known. This is also the reason why assessing the onset of endoreduplication is a key endeavour (Doležel et al. 2007; Ochatt 2008, 2011; Atif et al. 2013a, b; Wirsich et al. 2013). In this context, the physiological meaning of endoreduplication has remained speculative for a number of years, but the results with several species, including both model species and crops, have shown that endoreduplication is a phenomenon which is tightly associated with different stages of development within the plant (Nagl et al. 1983; Gendreau et al. 1998; Doležel et al. 2007; Ochatt 2008) including storage product accumulation in seeds and their subsequent germination (Atif et al. 2013a, b; Ochatt 2011; Wirsich et al. 2013). Thus, cell size, which is a major determinant of the final organ size, is strongly correlated with the nucleus size in the pea seed and embryo (Lemontey et al. 2000; Patrick and Stoddard 2010; Ochatt 2011; Ochatt 2013a, b).

\subsection{The phase of morphogenesis}

In recent years, we have developed a strategy for seed and embryo filling in vitro comparable to that observed in planta
(Gallardo et al. 2006a, b), which has proven useful for the study of a range of substances, from minerals (Gallardo et al. 2006a, b) to phytohormones (Ochatt 2011; Atif et al. 2013a, b; Wirsich et al. 2013), during the phases of growth (embryogenesis) and also of filling of both excised embryos and complete seeds, and coupled with the assessment of the contribution of the maternal tissues to those supplies (Ochatt 2011; Abirached-Darmency and Ochatt 2013). Moreover, this same strategy is being used to comparatively study normal (Atif et al. 2013a, b) and transgenic (Wirsich et al. 2013) or TILLING mutants (Le Signor et al. 2009) with different levels of expression of several genes involved in the development of seeds and embryos.

The maximum cell volume is an intrinsic limitation to the organ's storage product accumulation (Ochatt 2011, 2013a, b; Ochatt and Moessner 2010; Ochatt et al. 2008), with a strong incidence on the yield but also on the protein composition of the seed (Patrick and Stoddard 2010), as those protein fractions that accumulate the latest (Gallardo et al. 2006a, b, 2008; Le et al. 2007) may be penalised. In vitro approaches are an ideal tool for the study of the composition of the apoplastic liquid and the mitotic activity within the embryo, as they permit to vary the composition of the culture medium at will in order to reproduce that existing in vivo, but also enlarging it whilst retaining full control of the trophic and physical balances between metabolites (Atif et al. 2013a, b; Gallardo et al. 2006a, b; Ochatt 2011; Wirsich et al. 2013). Such approaches also permit to explore the part of control of the embryo genotype versus that of the maternal environment and to study the fundamental physiological mechanisms underlying the onset of embryogenesis (Atif et al. 2013a, b; Gallardo et al. 2006a, b; Ochatt 2011; Ochatt et al. 2008; AbirachedDarmency and Ochatt 2013), as related to variations in the hormonal balance of the medium (Atif et al. 2013a, b; Gallardo et al. 2006a, b; Ochatt 2011; Wirsich et al. 2013), but also through the kinetic study of flowering and fruiting induced in vitro (Atif et al. 2013a, b; Gallardo et al. 2006a, b; Ochatt 2011; Ochatt and Sangwan 2008, 2010; Ochatt et al. 2008; Ribalta et al. 2014; Mobini et al. 2014), followed by that of morphogenesis of the produced seeds (Atif et al. 2013a, b; Gallardo et al. 2006a, b; Ochatt 2011).

Against this background, we have studied the effect of the nutritional environment in vitro on the filling of excised immature embryos and immature seeds of pea and of M. truncatula. With the latter, we have examined media with different nitrogen contents, followed by their characterisation in terms of storage protein accumulation during growth (Gallardo et al. 2006a, b). Thus, with exogenous nitrogen added to the medium at the standard, normal concentration $(\mathrm{Nn})$ or at a high one $(\mathrm{Nh})$, both immature seeds and embryos develop and synthesise storage proteins as they would have done in planta, whereas in the absence or deficiency of nitrogen $(\mathrm{Nd})$, the development of immature embryos is arrested, 
whilst in seeds, there is a remobilisation of the endogenous nitrogen from the surrounding tissues during the early stage of embryo development (Gallardo et al. 2006a, b). Further studies assessed the responses of immature seeds and embryos at the same developmental stages on media where comparable concentrations of nitrogen (i.e. $\mathrm{Nd}, \mathrm{Nn}, \mathrm{Nh}$, plus an even higher one $\mathrm{Nh}^{+}$) were coupled with similarly varying contents in sulphur ( $\left.\mathrm{Sd}, \mathrm{Sn}, \mathrm{Sh}, \mathrm{Sh}^{+}\right)$, whereby the results observed in treatments with $\mathrm{Nd}$ and $\mathrm{Nn}$ were confirmed, whilst an increased nitrogen content in the medium $(\mathrm{Nh})$ perturbed mitoses, and the highest nitrogen level $\mathrm{Nh}^{+}$resulted in a complete arrest of cell divisions. In addition, under a $\mathrm{Nn} / \mathrm{Sd}$ regime, the synthesis of a protein of a molecular weight similar to that of albumin $2 \mathrm{~S}$ was reduced, whilst it increased in a $\mathrm{Nn} / \mathrm{Sh}$ situation, as also observed for chain $\beta$ legumins and shown in Fig. 6 (Ochatt 2011). These observations were also confirmed in immature seeds and embryos of pea (unpublished data), and the nitrogen and carbon supply are known to alter the flux of metabolites in developing seeds of soybean (Allen and Young 2013), common bean (Cuellar-Ortiz et al. 2008) and faba bean (Patrick and Stoddard 2010), too.

\subsection{Auxin in embryo development, seed filling and endoreduplication}

Auxin is a phytohormone that is implicated in nearly every aspect of plant growth and development (Hooykaas et al. 1999; Woodward and Bartel 2005; Ochatt 2011; Forestan et al. 2012; Atif et al. 2013a, b). In this respect, it acts always in concert with other growth regulators and plays a key role in processes such as tropic responses (Abel and Theologis 1996; Hooykaas et al. 1999; Woodward and Bartel 2005; Forestan

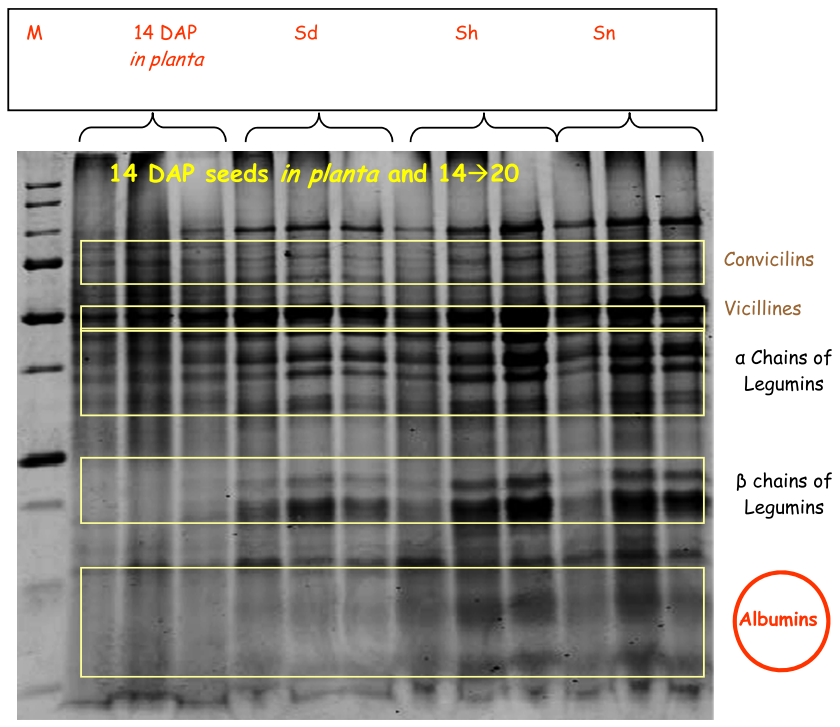

Fig. 6 Electrophoresis of storage proteins from immature seeds of M. truncatula at 14 DAP (days after pollination) and cultured in vitro for 6 days on media with variable sulphur contents et al. 2010, 2012; Hayashi 2012), cell division and elongation (Lur and Setter 1993; Abel and Theologis 1996; Hooykaas et al. 1999; Hayashi 2012; Atif et al. 2013a, b), apical dominance (Abel and Theologis 1996; Hayashi 2012; Forestan et al. 2012), fruit ripening and bud formation (Hooykaas et al. 1999; Forestan et al. 2012). The hormone is always distributed differentially within the plant tissues and elicits different cellular responses depending on its concentration (Hooykaas et al. 1999; Ishida et al. 2009; Vanneste and Friml 2009; Forestan et al. 2010). These concentration gradients are established and maintained by de novo biosynthesis, deconjugation and intercellular transport in the tissues and can be reduced through conjugation or degradation of the molecules (Hooykaas et al. 1999; Woodward and Bartel 2005; Ishida et al. 2009; Vanneste and Friml 2009; Hayashi 2012).

In general, the synthesis of hormones in plants is not restricted to a particular, specialised tissue, but auxin is primarily produced in shoot apical regions, young leaves and developing leaf primordia (Woodward and Bartel 2005; Vanneste and Friml 2009), through a tryptophan (Trp)-independent or several Trp-dependent pathways for the synthesis of indole-3acetic acid (IAA) (Hooykaas et al. 1999; Woodward and Bartel 2005; Ishida et al. 2009; Vanneste and Friml 2009). Whilst it is still imprecise which pathway the plant uses during specific physiological processes or why, it is known that the synthesis of Trp and its conversion to IAA are not simultaneous (Hooykaas et al. 1999). Mutation studies in Zea mays and A. thaliana have shown that plants can switch from the Trp-independent to the Trp-dependent pathway when more IAA is needed, e.g. during stress (Woodward and Bartel 2005).

Within the cell, auxin exerts its physiological effects through transcriptional regulation, whereas the spatiotemporal presence of auxin in varying concentrations is responsible for gene regulation (Abel and Theologis 1996; Ishida et al. 2009; Vanneste and Friml 2009; Ochatt et al. 2010; Hayashi 2012; Atif et al. 2013a, b). In this regard, the influence of auxin in modulating the switch from mitotic cycles to endocycles has already been demonstrated ( $\mathrm{Li}$ et al. 2005; Elmaghrabi and Ochatt 2006; Larson-Rabin et al. 2009; Lee et al. 2010). As referred to seed development, auxin was recently shown to have a strong impact on the onset but also on the duration of endoreduplication in developing seeds of M. truncatula, and it was also shown that this depended both on the developmental stage at the time of hormonal treatment and on the type of auxin used (Atif et al. 2013a, b; Wirsich et al. 2013). More precisely, these authors showed a possible role of auxin in prolonging endoreduplication whilst favouring sustained cell division. Conversely, in a previous study, high auxin levels had been shown to inhibit and delay endocycles in root meristems of A. thaliana, whilst the cells entered endoreduplication in low auxin conditions (Larson-Rabin et al. 2009). Taken together, these results indicate that auxin would be involved in 
downregulating the CDKs at the transition from the $\mathrm{G} 2$ to the $\mathrm{M}$ phase of the cell cycle, thereby resulting in the skip of mitoses whilst still permitting DNA replication (Ishida et al. 2009). As a consequence, the entry and exit from endoreduplication might be linked processes where auxin signalling plays a major role (Ishida et al. 2009; Forestan et al. 2010; Atif et al. 2013a, b; Wirsich et al. 2013).

Thus, parallel to the study on the effects on seed development and filling of the mineral composition of the medium, we also analysed the effects of several phytohormones. Thus, we first examined the effects of abscisic acid (ABA), coupled with the in situ characterisation of formed tissues, the determination of their mitotic index and also the immunolocalisation of several storage protein fractions and of ABA (Ochatt 2011). Adding ABA to the culture medium at the transition stage between embryo morphogenesis and seed maturation showed that seed development does not in fact consist of a succession of fixed and distinct phases but is more a continuous progression of events instead. Thus, cell divisions and endoreduplication coexist and the accumulation of storage products starts from the onset of a slowdown of cell divisions, which is parallel to a decrease of protein accumulation in the absence of ABA but can be restored by adding exogenous ABA. In separate experiments, exogenous gibberellin (GA) increased the mitotic index and provoked a longer duration of the cell division phase, concomitant with the disappearance of the endoreduplication peaks and associated with a belated start of the storage product accumulation phase. In addition, GA+ ABA mixtures countered the effect of ABA, with seeds and embryos recovering a normal germination capacity, but starting to germinate earlier and to accumulate storage products later (Ochatt 2011). More recently, during studies on the effects of auxins, immature $M$. truncatula seeds at 8 to 12 DAP saw their fresh weight and surface area increase significantly in the presence of IBA and even more of NAA and coupled with a pursuit of cell divisions and prolonged endoreduplicated cycles (Atif et al. 2013a, b). The next step will be to assess the effects of cytokinins. Most recently, when analysing separately the different tissues in the immature seed, it was possible to show that the strongest endoreduplication occurs in the seed coats, whilst the embryo tissues remain mostly diploid and show negligible or no endoreduplication at all throughout the whole duration of the embryogenesis phase (Abirached-Darmency and Ochatt 2013).

\section{Functional validation of genes of interest by transformation}

Le Signor et al. (2009) produced a large population of TILLING mutant in M. truncatula which, amongst many others, included several knock-out mutants of the gene
DOF1147, which are incapable of producing seeds reaching maturity. Profiting of the availability of reliable methods for the genetic transformation of M. truncatula (Trinh et al. 1998; Atif 2012; Ochatt et al. 2013), a 35S::Dof1147-gfp transformed line exhibiting a strong GFP expression was generated, aimed at validating the involvement of the gene DOF1147 in the seed filling process through its overexpression (Atif 2012). Then, assessments using the strategy for in vitro embryo development and seed filling above (Gallardo et al. 2006a, b; Ochatt 2011) were extended by Wirsich et al. (2013) to this transformants. In this regard, the transcription factor DOF1147 has been identified to be involved in embryo development and seed filling in wild-type seeds of the model legume $M$. truncatula, whereby the transcript expression starts at the transition from the cell division to the storage protein accumulation phase during seed development and reaches its peak at the mid-seed filling stage (Verdier et al. 2008; Atif 2012; Noguero et al. 2013). Moreover, as already evoked above, this transition phase is known to be indicated by the switch from mitotic cycles to endocycles which is, in turn, modulated by auxin. Therefore, seeds of a wild-type genotype of the model legume M. truncatula and of transformants overexpressing the gene $D O F 1147$ were harvested at different development stages and cultured on different auxincontaining media. The in vitro development, DNA content, seed surface area and fresh weight of the immature seeds were studied. The results obtained validated the role of this transgene, through an increased production of seeds of a bigger size by the transformants and associated with a better response to auxins. In this respect, transformed seeds exhibited an earlier onset of endoreduplication and maintenance of endocycles for a longer time than the wild-type seeds, irrespective of the presence or absence of exogenous auxin in the culture medium, and their response to auxins was significantly higher than that of the wild-type seeds (Wirsich et al. 2013). At this stage, and through the summation of results obtained in recent years with $M$. truncatula, it can be proposed that the embryo development and seed filling processes in this species are affected by a number of factors as schematized in Fig. 7.

The study of embryogenesis in situ in plants is complicated by the fact that the embryo bathes in the endosperm and is covered by tissues from the ovule that will generate the seed coat (Ochatt 2011; Abirached-Darmency and Ochatt 2013), whereby they are difficult to access and not really adapted to tissue dissection as would be required for biochemical studies for instance. Conversely, somatic embryogenesis from differentiated organs furnishes an alternative experimental system for the in-depth research of the cellular and molecular determinism and control of embryogenesis, the latter being not yet completely understood (Gutierrez et al. 2007; Mordhorst et al. 1997). In this respect, the transition from the dedifferentiated status to the embryogenic one is complex and includes a number of phases (dedifferentiation, cell reactivation, cell 
Fig. 7 Growth curve of an embryo with the three developmental phases up to seed filling and maturation and in medallion the corresponding flow cytometry profiles at each stage plus, in abscissa, in red factors that are negative and in green positive ones. The effect of using a transformant line with Dof1147 as a promoter or with $35 \mathrm{~S}$ promoter as related to the effect of auxin on endoreduplication (Wirsich et al. 2013) is also indicated

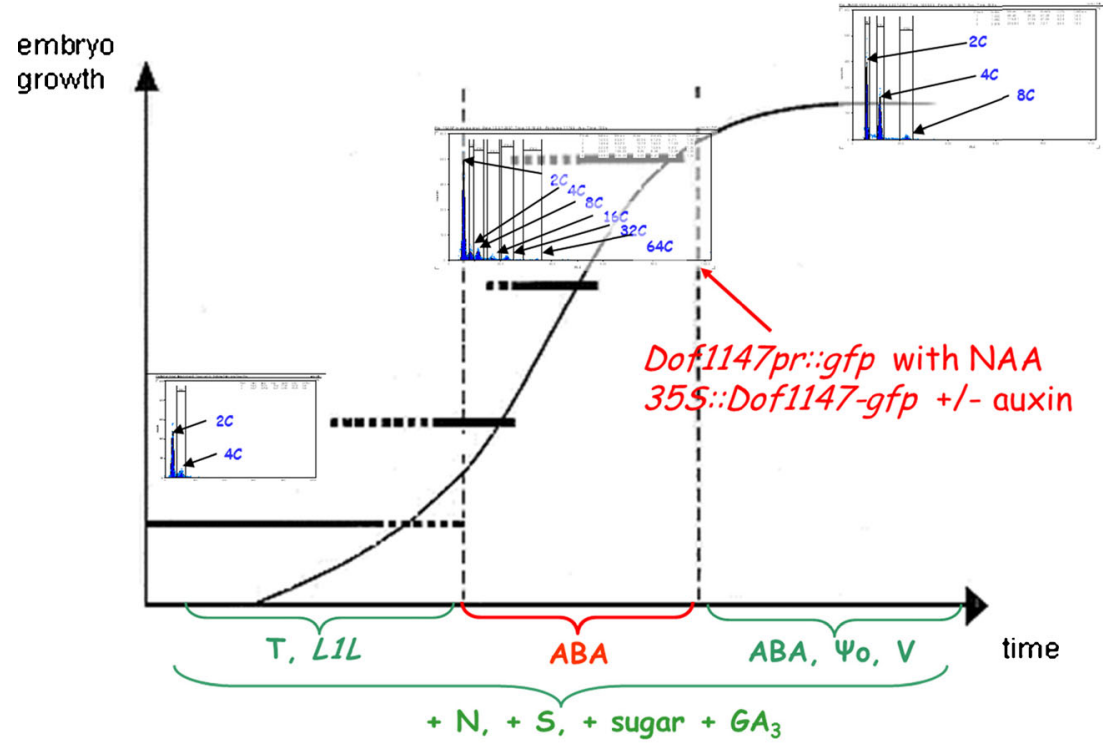

division) and a severe metabolic and developmental reprogramming (Fehér et al. 2003). On the other hand, as already discussed above, endoreduplication has a strong effect on all phases of development, including amongst others on the capacity to regenerate plants from protoplasts in pea (Ochatt et al. 2000a, b) or from undifferentiated tissues in M. truncatula (Elmaghrabi and Ochatt 2006; Ochatt 2008), and also on the number of tissue layers formed during organogenesis in vitro in various protein legumes (Ochatt et al. 2002a, b, 2007). Other early markers of the acquisition of embryogenesis competence identified in legume cell suspension cultures include the intracellular and medium osmolarity, the cell surface and cell wall thickness (Ochatt et al. 2008).

\section{The link between cell cycle, embryogenesis and seed filling as affected by abiotic stress agents}

Over the years, a series of different physical abiotic factors has been shown to have an impact on the acquisition of competence for in vitro regeneration from cultured protoplasts, cells, tissues and organs, and several of these factors have been studied in detail aimed at understanding the physiological mechanism(s) underlying such effect. Amongst them are electroporation (Rech et al. 1987, 1988; Ochatt 2013a, b), heat and cold shocks (Lülsdorf et al. 2011), osmotic stresses (Lionneton et al. 2000; Delaitre et al. 2001; Germanà 2006; Ochatt et al. 2010), centrifugation (Grewal et al. 2009) and sonication (Ribalta et al. 2012; Teixeira da Silva and Dobránszki 2014).

Electroporation effects on inducing regeneration competence from hitherto non- (or low) regenerating cells, tissues and organs have made the object of a very recent review (Ochatt 2013a, b) and will thus not be discussed herein.
Osmotic stresses have been frequently used for the induction of androgenesis from isolated microspores and for a number of species (Touraev et al. 1997; Lionneton et al. 2000; Ochatt et al. 2009; Ribalta et al. 2012), whilst temperature stress as either heat or cold has also been reported to improve or sometimes even induce androgenesis, gynogenesis and, more generally, embryogenesis from a number of cells and tissues (Lülsdorf et al. 2011). Finally, centrifugation and sonication (Rokhina et al. 2009; Wei et al. 2012; Teixeira da Silva and Dobránszki 2014) have also reportedly improved the embryogenesis and organogenesis competence of in vitro cultured tissues. Thus, Trick and Finer $(1997,1998)$ were amongst the first to use sonication in biotechnology within the context of Agrobacterium-mediated transformation, aimed at facilitating entry of the bacteria into the co-cultured tissues to increase transgenesis efficiency, and this has since become routine in transformation experiments. In addition, sonication also proved useful to foster embryogenesis from isolated microspores (Ribalta et al. 2012) and to increase regeneration in a range of tissues of various species (Teixeira da Silva and Dobránszki 2014), which was partly attributed to the effect of sonication on their cell cycle (Wang et al. 2003a) and hormonal status (Wang et al. 2003b, 2009).

In recent studies carried out in order to induce salt stress tolerance to $M$. truncatula, calluses were cultured in the presence of increasing concentrations of $\mathrm{NaCl}$ and included, amongst parameters measured as fresh and dry weight, tissue osmolarity, and the concentration of total soluble sugars and proline content, the cell cycle status and the expression of various target genes were also analysed by Elmaghrabi et al. (2013). Then, homeostasis between $\mathrm{Na}^{+}$and $\mathrm{K}^{+}$occurred at $100-150 \mathrm{mM} \mathrm{NaCl}$, which is significant as this is also a level at which somatic embryogenesis from the tolerant calluses was not only unaffected but even favoured. Moreover, the 
expression of several genes involved in the control of growth and development (WEE1), somatic embryogenesis (SERK), proline synthesis (P5CS), salt tolerance (SOS1) and also of cell cycle and ploidy level (WEE1 and CCS52) was significantly higher at this $\mathrm{NaCl}$ concentration. Interestingly also, over-regulation of the expression of WEE 1 by a salt stress (Elmaghrabi et al. 2013) had not been reported before. Taken together, these results showed the crucial role of several genes for the control of embryogenesis as linked to stress (Mordhorst et al. 1997; Lotan et al. 1998; Stone et al. 2001; Henderson et al. 2004; Li et al. 2005; Gaj et al. 2005; Gutierrez et al. 2007), and in turn, such genes become good candidate genes as regulators and coordinators of the successive phases of embryo morphogenesis and seed filling.

With respect to WEE1, its expression is associated with endoreduplication (Nagl et al. 1983; Doležel et al. 2007; Ochatt 2008) observed in tomato fruits (Gonzalez et al. 2004, 2007), in maize endosperm (Sun et al. 1999) and, as evoked before, in developing embryos and seeds of M. truncatula (Ochatt 2008, 2011; Atif et al. 2013a, b; Wirsich et al. 2013) and other legumes (Ochatt 2011). It is also of interest in this context that endoreduplication has been associated in the past with abiotic stress in Arabidopsis (Skirycz et al. 2011). WEE1 is a negative regulator of cell division and is strongly expressed during DNA replication phase as well as at the checkpoints of DNA damage during the cell cycle (De Schutter et al. 2007; de Lorenzo et al. 2009), but its role in other kinds of stress had seldom been studied until Elmaghrabi et al. (2013) showed its overexpression under the effect of $\mathrm{NaCl}$ stress. WEE1 inhibits the activity of kinase protein complexes that regulate the cell cycle, including the CDK, via the phosphorylation of tyrosine 15 (Shimotohno and Umeda 2007). In A. thaliana, maximum WEE1 expression is observed in rapidly proliferating tissues (Sorrell et al. 2002). Contrasting this, overexpression of the tomato homo$\log$ Solly;WEE1 in tobacco cells delayed mitoses (Gutierrez et al. 2007) and using a strong promoter to overexpress Arath;WEE1 affected root growth and blocked cells in the G2 phase of mitosis (de Lorenzo et al. 2009). Likewise, WEE1 overexpression repressed growth and development in A. thaliana (Spadafora et al. 2012a, b), with cells in the root meristems of transformants exhibiting a delayed time of division which resulted in shorter and less ramified roots.

The exploration of the close environment of soil by roots aimed at optimising their growth operates through a complex of cascade signal that has been studied in great detail in chez A. thaliana, where several Receptor-Like Kinases (RLKs) present in the cell surface play a paramount role in the detection of external signals regulating gene expression (Lease et al. 1998). Also in A. thaliana, the gene SOS1 (Salt Overly Sensitive 1) codes for a membrane-specific $\mathrm{Na}^{+} / \mathrm{H}^{+}$antiporter (Shi et al. 2002), regulated by SOS2 and SOS3, and the $\operatorname{sos} 1$ mutants were hypersensitive to $\mathrm{NaCl}$ (Qiu et al. 1999), whilst mutant complementation via the constitutive expression of SOS1 restored their tolerance to salt (Ishitani et al. 2000). Conversely, due to their ability to establish symbiotic interactions, legume roots exhibit important physiological differences compared with those of other species. Thus, in the roots of M. truncatula, a leucine-rich RLK gene, Srlk, which is rapidly induced by a salt stress has been identified and it was shown that Srlk RNAi mutants produced transgenic roots whose growth was less inhibited by the presence of salts in the medium (Dalmais et al. 2008). Moreover, even if these authors could not identify the SOS1 homolog in M. truncatula, they showed with GUS fusions that the gene was expressed in the root epidermis as a response to stress. We have also recently shown an overexpression of SOS1 in tolerant tissues of M. truncatula cultured in the presence of $100-150 \mathrm{mM}$ $\mathrm{NaCl}$ (Elmaghrabi et al. 2013).

As far as CCS52 (cell cycle switch) gene is concerned, in Arabidopsis, this is a key marker gene of endoreduplication (Larson-Rabin et al. 2009), whose overexpression in M. sativa by differentiating cells undergoing endoreduplication was partially reversed in transgenic plants overexpressing CCS52 in antisense orientation (Cebolla et al. 1999). This has also highlighted the effect of CCS52 on endopolyploidy and cell size in transgenic $M$. truncatula, suggesting that the product of $\operatorname{ccs} 52$ could modify the status of proliferating cells towards differentiation programmes, with endoreduplication provoking a larger cell size, as also shown elsewhere (Doležel et al. 2007; Ochatt 2008; Atif et al. 2013a, b; Elmaghrabi et al. 2013). In our studies on in vitro selection for salt tolerance in M. truncatula, CCS52 was one of the genes that was overexpressed in calli subjected to $100-150 \mathrm{mM} \mathrm{NaCl}$ and was coupled with the onset of endoreduplication, preceding the acquisition of tolerance to water and ionic stress provoked by $\mathrm{Na}^{+}$and of embryogenic competence (Elmaghrabi et al. 2013).

\section{Conclusion}

The constant increase in the world's population results in an ever-growing demand for food and feed and is faced with the fact that the area of crop cultivation remains constant or even is reduced when the same increased population generates a number of stresses that affect both the soil and the plants growing on it (Branca et al. 2013, http://www.ucsusa.org/ food_and agriculture/our-failing-food-system/geneticengineering/biotechnology-and-the-world.html). As a result, even if developed countries do not suffer much of it as yet, nearly one billion people do not get enough to eat and more than 700 million are chronically malnourished in low-income food-deficit countries, and this situation will worsen unless the global food supply is ensured. Under such circumstances, there is an urgent need for fundamental changes to the global 
food-producing system in order to be able to feed the expanding population and the paramount research challenge of the twenty-first century will be to balance population increase and food supply. Against this background, crop improvement will be indispensable to fulfil these requirements, and biotechnology-based breeding approaches are prone to becoming major players in the achievement of that aim. This will be particularly important for the control and modulation of the impact on yield of stresses induced by biotic and abiotic agents.

Biotechnological tools may play a major role in the rapid generation of genetic novelties with improved tolerance/ resistance to various agents of stress, both biotic and abiotic, and hence ameliorating and speeding up the acquisition of such agronomical traits that will help in the maintenance of a more sustainable agriculture. Likewise, they will greatly contribute to the better understanding of the genetic, physiological and environmental mechanism(s) responsible for an acceptable yield, even under stressful conditions. This article has discussed the importance of an efficient development of immature embryos and the subsequent seed filling in legumes and has also addressed the link between these processes in vivo and in vitro, notably aiming at sidestepping the barriers for the recovery of fertile plants from somatic embryos induced in vitro. The development and exploitation of biotechnological breeding has already started for a number of crops and it can only gain pace once the still existing difficulties for plant regeneration of the so-called recalcitrant genotypes, including legume crops, are also unravelled.

Acknowledgments Valuable guidance from Eric Lichtfouse and staff on the formatting of the manuscript is gratefully acknowledged. C. Delaitre and B. Raffiot, from INRA Dijon, are gratefully acknowledged for the supply of the photos of plants in the field used in Fig. 2.

\section{References}

Abel S, Theologis A (1996) Early genes and auxin action. Plant Physiol 111:9-17. doi:10.1104/pp.111.1.9

Abirached-Darmency M, Abdel-Gawwad MR, Verdeil JL, Thompson R (2005) In situ expression of two storage protein genes in relation to histo-differentiation at mid-embryogenesis in Medicago truncatula and Pisum sativum seeds. J Exp Bot 56:2019-2028. doi:10.1093/ $\mathrm{jxb} / \mathrm{eri} 200$

Abirached-Darmency M , Ochatt S (2013) Impact of endopolyploidy on seed development and cell expansion in Medicago truncatula. 4ème Colloque Graines (30-31/10/2013, Dijon, France), P02

Aghamirzaie D, Nabiyouni M, Fang Y, Klumas C, Heath LS, Grene R, Collakova E (2013) Changes in RNA splicing in developing soybean (Glycine max) embryos. Biology 2:1311-1337. doi:10.3390/ biology2041311

Allen DK, Young JD (2013) Carbon and nitrogen provisions alter the metabolic flux in developing soybean embryos. Physiology 161: 1458-1475. doi:10.1104/pp.112.203299
Allen DK, Ohlrogge JB, Shachar-Hill Y (2009) The role of light in soybean seed filling metabolism. Plant J 58:220-234. doi:10.1111/ j.1365-313X.2008.03771.x

Atif RM (2012) Dissecting the factors controlling seed development in the model legume Medicago truncatula. $\mathrm{PhD}$ thesis, Univ Bourgogne, Ecole Doctorale Environnement-Santé-STICE2SUMR

Atif RM, Patat-Ochatt EM, Svabova L, Ondrej V, Klenoticova H, Jacas L, Griga M, Ochatt SJ (2013a) Gene transfer in legumes. Progr Bot 74: 37-100. doi:10.1007/978-3-642-30967-0 2

Atif RM, Boulisset F, Conreux C, Thompson R, Ochatt SJ (2013b) In vitro auxin treatment promotes cell division and delays endoreduplication in developing seeds of the model legume species Medicago truncatula. Physiol Plant 148:549-559. doi:10.1111/j. 1399-3054.2012.01719.x

Barker DG, Bianchi S, Blondon F, Dattée Y, Duc G, Essad S, Flament P, Gallusci P, Génier G, Guy P, Muel X, Tourneur J, Dénarié J, Huguet T (1990) Medicago truncatula, a model plant for studying the molecular genetics of the Rhizobium-legume symbiosis. Plant Mol Biol Rep 8:40-49. doi:10.1007/BF02668879

Bataillon T, Ronfort J (2006) Evolutionary and ecological genetics of Medicago truncatula. In: Medicago truncatula handbook

Baud S, Boutin JP, Miquel M, Lepiniec L, Rochat C (2002) An integrated overview of seed development in Arabidopsis thaliana ecotype WS Plant Physiol Biochem 40:151-160. doi:10.1016/S0981-9428(01) 01350-X

Baud S, Wuillème S, Lemoine R, Kronenberger J, Caboche M, Lepiniec L, Rochat C (2005) The AtSUC5 sucrose transporter specifically expressed in the endosperm is involved in early seed development in Arabidopsis. Plant J 43:824-836. doi:10.1111/j.1365-313X.2005. 02496.x

Blondon F, Marie D, Brown S, Kondorosi A (1994) Genome size and base composition in Medicago sativa and M. truncatula species. Genome 37:264-270. doi:10.1139/g94-037

Borisjuk L, Nguyen TH, Neuberger T, Rutten T, Tschiersch H, Claus B, Feussner I, Webb AG, Jakob P, Weber H, Wobus U, Rolletschek H (2005) Gradients of lipid storage, photosynthesis and plastid differentiation in developing soybean seeds. New Phytol 167:761-776. doi:10.1111/j.1469-8137.2005.01474.x

Branca G, Lipper L, McCarthy N, Jolejole MC (2013) Food security, climate change, and sustainable land management. A review. Agron Sustain Dev 33:635-650. doi:10.1007/s13593-013-0133

Campanelli A, Ruta C, Morone-Fortunato I, De Mastro G (2013) Alfalfa (Medicago sativa $\mathrm{L}$.) clones tolerant to salt stress: in vitro selection. Cent Eur J Biol 8:765-776. doi:10.2478/s11535-013-0194-1

Cebolla A, Vinardeli JM, Kiss E, Olàh B, Roudier F, Kondorosi A, Kondorosi E (1999) The mitotic inhibitor ccs52 is required for endoreduplication and ploidy-dependent cell enlargement in plants. EMBO J 18:4476-4484. doi:10.1093/emboj/18.16.4476

Christou P (2013) Plant genetic engineering and agricultural biotechnology 1983-2013. Trends Biotechnol 31:125-127. doi:10.1016/j. tibtech.2013.01.006

Confalonieri M, Carelli M, Galimberti V, Macovei A, Panara F, Biggiogera M, Scotti C, Calderini O (2014) Seed-specific expression of AINTEGUMENTA in Medicago truncatula led to the production of larger seeds and improved seed germination. Plan Mol Biol Rep. doi:10.1007/s11105-014-0706-4

Cuellar-Ortiz SM, Arrieta-Montiel MP, Acosta-Gallegos J, Covarrubias AA (2008) Relationship between carbohydrate partitioning and drought resistance in common bean. Plant Cell Environ 31:1399 1409. doi:10.1111/j.1365-3040.2008.01853.x

Dalmais M, Schmidt J, Le Signor C, Moussy F, Burstin J, Savois V, Aubert G, Brunaud V, de Oliveira Y, Guichard C, Thompson R, Bendahmane A (2008) UTILLdb, a Pisum sativum in silico forward and reverse genetics tool. Genome Biol 9:R43. doi:10.1186/gb2008-9-2-r43 
Delaitre C, Ochatt S, Deleury E (2001) Electroporation modulates the embryogenic responses of asparagus (Asparagus officinalis L.) microspores. Protoplasma 216:39-46. doi:10.1007/BF02680129

de Lorenzo L, Merchan F, Laporte P, Thompson R, Clarke J, Sousa C, Crespi M (2009) A novel plant LRR receptor kinase regulates the response of Medicago truncatula roots to salt stress. Plant Cell 21: 668-680. doi:10.1105/tpc. 108.059576

De Schutter K, Joubes J, Cools T, Verkest A, Corellou F, Babiychuk E, Der Schueren E-V, Beeckman T, Kushnir S, Inze D, De Veylder L (2007) Arabidopsis WEE1 kinase controls cell cycle arrest in response to activation of the DNA integrity checkpoint. Plant Cell 19: 211-225. doi:10.1105/tpc. 106.045047

Dita MA, Rispail N, Prats E, Rubiales D, Singh KB (2006) Biotechnology approaches to overcome biotic and abiotic stress constraints in legumes. Euphytica 147:1-24. doi:10.1007/s10681006-6156-9

Doležel J, Greilhuber J, Suda J (eds) (2007) Flow cytometry with plant cells. Analysis of genes, chromosomes and genomes. Wiley-VCH Verlag, Weinheim. P.455. ISBN: 978-3-527-31487-4

Duc G, Page D, Sagan M, Viroben G, Gueguen J (1997) Effect of nitrogen nutrition pathways on the quality of nitrogen storage compounds in legumes In: Biological fixation of nitrogen for ecology and sustainable agriculture (eds Legocki A, Bothe H, Pühler A.); pp. 275-278. ISBN: 1996-09-10-1996-09-14

Duclercq J, Sangwan-Norreel B, Catterou M, Sangwan RS (2011) De novo shoot organogenesis: from art to science. Trends Plant Sci 16: 597-606. doi:10.1016/j.tplants.2011.08.004

Elmaghrabi A, Ochatt S (2006) Isoenzymes and flow cytometry for the assessment of true-to-typeness of calluses and cell suspensions of barrel medic prior to regeneration. Plant Cell Tissue Org Cult 85:3143. doi:10.1007/s11240-005-9046-2

Elmaghrabi AM, Ochatt S, Rogers HJ, Francis D (2013) Enhanced tolerance to salinity following cellular acclimation to increasing $\mathrm{NaCl}$ levels in Medicago truncatula. Plant Cell Tissue Org Cult 114:61-70. doi:10.1007/s11240-013-0306-2

Esumi T, Tao R, Yonemori K (2005) Isolation of LEAFY and TERMINAL FLOWER 1 homologues from six fruit tree species in the subfamily Maloideae of the Rosaceae. Sex Plant Reprod 17: 277-287. doi:10.1007/s00497-004-0239-3

Esumi T, Kitamura Y, Hagihara C, Yamane H, Tao R (2010) Identification of a TFL1 ortholog in Japanese apricot (Prunus mume Sieb. et Zucc.). Sci Hortic 125:608-616. doi:10.1016/j.scienta.2010. 05.016

FAO, Food and Agriculture Organization of the United Nations (2012) FaoStat. Accessed 05 Dec 2013. http://faostat3.fao.org/faostatgateway/go/to/download/Q/QC/E

Fehér A, Pasternak TA, Dudits D (2003) Transition of somatic plant cells to embryogenic state. Plant Cell Tissue Org Cult 74:201-228. doi: 10.1023/A: 1024033216561

Forestan C, Meda S, Varotto S (2010) ZmPIN1-mediated auxin transport is related to cellular differentiation during maize embryogenesis and endosperm development. Plant Physiol 152:1373-1390. doi:10. 1104/pp.109.150193

Forestan C, Farinati S, Varotto S (2012) The maize PIN gene family of auxin transporters. Front Plant Sci 3:1-23. doi:10.3389/fpls.2012. 00016

Gaj MD, Zhang S, Harada JJ, Lemaux PG (2005) Leafy cotyledon genes are essential for induction of somatic embryogenesis of Arabidopsis. Planta 222:977-988. doi:10.1007/s00425-005-0041-y

Gallardo K, Le Signor C, Vandekerckhove J, Thompson RD, Burstin J (2003) Proteomics of Medicago truncatula seed development establishes the time frame of diverse metabolic processes related to reserve accumulation. Plant Physiol 133:664-682. doi:10.1104/pp. 103.025254

Gallardo K, Kurt C, Thompson R, Ochatt S (2006a) In vitro culture of immature $\mathrm{M}$. truncatula grains under conditions permitting embryo development comparable to that observed in vivo. Plant Sci 170: 1052-1058. doi:10.1016/j.plantsci.2005.12.021

Gallardo K, Lesignor C, Darmency M, Burstin J, Thompson R, Rochat C, Boutin J, Kuester H, Buitink J, Leprince O, Limami A, Grusak MA (2006) Seed biology of Medicago truncatula. In: Mathesius U. Ardmore (ed) The Medicago truncatula handbook. OK: The Samuel Roberts Noble Foundation. http://www.noble.org/ MedicagoHandbook/

Gallardo K, Thompson R, Burstin J (2008) Reserve accumulation in legume seeds. C R Biol 331:755-762. doi:10.1016/j.crvi.2008.07.017

Garcia J, Barker DG, Journet E (2006) Seed storage and germination. In: Medicago truncatula handbook

Gendreau E, Hofte H, Grandjean O, Brown S, Traas J (1998) Phytochrome controls the number of endoreduplication cycles in the Arabidopsis thaliana hypocotyl. Plant J 13:221-230. doi:10. 1046/j.1365-313X.1998.00030.x

Germanà MA (2006) Doubled haploid production in fruit crops. Plant Cell Tissue Organ Cult 86:131-146. doi:10.1007/s11240-006-9088-0

Gianinazzi-Pearson V (1996) Plant cell responses to arbuscular mycorrhizal fungi: getting to the roots of the symbiosis. Plant Cell 8:18711883. doi:10.1105/tpc.8.10.1871

Golombek S, Rolletschek H, Wobus U et al (2001) Control of storage protein accumulation during legume seed development. J Plant Physiol 158:457-464. doi:10.1078/0176-1617-00357

Gonzalez N, Hernould M, Delmas F, Gevaudant F, Duffe P, Causse M, Mouras A, Chevalier C (2004) Molecular characterization of a WEE1 gene homologue in tomato (Lycopersicon esculentum Mill.). Plant Mol Biol 56:849-861. doi:10.1007/s11103-004-5110-2

Gonzalez N, Gevaudant F, Hernould M, Chevalier C, Mouras A (2007) The cell cycle associated protein kinase WEE1 regulates cell size in relation to endoreduplication in developing tomato fruit. Plant J 51: 642-655. doi:10.1111/j.1365-313X.2007.03167.x

Grafi G (1998) Cell cycle regulation of DNA replication: the endoreduplication perspective. Exp Cell Res 244:372-378. doi:10. 1006/excr.1998.4213

Grewal RK, Lulsdorf M, Croser J, Ochatt S, Vandenberg A, Warkentin TD (2009) Doubled-haploid production in chickpea (Cicer arietinum L.): role of stress treatments. Plant Cell Rep 28:1289 1299. doi:10.1007/s00299-009-0731-1

Gutierrez L, Van Wuytswinkel O, Castelain M, Bellini C (2007) Combined networks regulating seed maturation. Trends Plant Sci 12:294-300. doi:10.1016/j.tplants.2007.06.003

Hanano S, Goto K (2011) Arabidopsis TERMINAL FLOWER1 is involved in the regulation of flowering time and inflorescence development through transcriptional repression. Plant Cell 23:31723184. doi:10.1105/tpc. 111.088641

Hao J, You C, Deng X (2002) Cell size as a morphological marker to calculate the mitotic index and ploidy level of citrus callus. Plant Cell Rep 20:1123-1127. doi:10.1007/s00299-002-0460-1

Hayashi K (2012) The interaction and integration of auxin signaling components. Plant Cell Physiol 53:965-975. doi:10.1093/pcp/ pcs 035

Henderson JT, Li HC, Rider SD, Mordhorst AP, Romero-Severson J, Cheng J-C, Robey J, Sung ZR, de Vries SC, Ogas J (2004) PICKLE acts throughout the plant to repress expression of embryonic traits and may play a role in gibberellin-dependent responses. Plant Physiol 134:995-1005. doi:10.1104/pp.103.030148

Hoffmann B, Trinh TH, Leung J, Kondorosi A, Kondorosi E (1997) A new Medicago truncatula line with superior in vitro regeneration, transformation, and symbiotic properties isolated through cell culture selection. Mol Plant Microb Interact 10:307-315. doi:10.1094/ MPMI.1997.10.3.307

Hooykaas PJJ, Hall MA, Libbenga KR (1999) Biochemistry and molecular biology of plant hormones, 1st ed. New comprehensive biochemistry v.33. Elsevier, Amsterdam, New York. ISBN 0444803033/ 572 s.571.7/42 
Igasaki T, Watanabe Y, Nishiguchi M, Kotoda N (2008) The FLOWERING LOCUS T/TERMINAL FLOWER 1 family in Lombardy poplar. Plant Cell Physiol 49:291-300. doi:10.1093/ $\mathrm{pcp} / \mathrm{pcn} 010$

Ikeuchi M, Sugimoto K, Iwase A (2013) Plant callus: mechanisms of induction and repression. Plant Cell 25:3159-3173. doi:10.1105/ tpc. 113.116053

Ishida T, Adachi S, Yoshimura M, Shimizu K, Umeda M, Sugimoto K (2009) Auxin modulates the transition from the mitotic cycle to the endocycle in Arabidopsis. Development 137:63-71. doi:10.1242/ dev.035840

Ishitani M, Liu JP, Halfter U, Kim CS, Shi WM, Zhu JK (2000) SOS3 function in plant salt tolerance requires $\mathrm{N}$-myristoylation and calcium binding. Plant Cell 12:1667-1677. doi:10.1105/tpc.12.9.1667

Jones SI, Gonzalez DO, Vodkin LO (2010) Flux of transcript patterns during soybean seed development. BMC Genomics 11:1360. doi: 10.1186/1471-2164-11-136

Joubès J, Chevalier C (2000) Endoreduplication in higher plants. Plant Mol Biol 43:735-745. doi:10.1023/A:1006446417196

Joubès J, Phan T-H, Just D, Rothan C, Bergounioux C, Raymond P, Chevalier C (1999) Molecular and biochemical characterization of the involvement of cyclin-dependent kinase CDKA during the early development of tomato fruit. Plant Physiol 121:857-869. doi:10. 1104/pp.121.3.857

Journet E, Carreau V, Gouzy J et al. (2001) La légumineuse modèle Medicago truncatula: approches génomiques et perspectives. Oléagineux, Corps Gras, Lipides 8:478-484. ISSN:1258-8210

Kurdyukov S, Song Y, Sheahan MB, Rose RJ (2014) Transcriptional regulation of early embryo development in the model legume Medicago truncatula. Plant Cell Rep 33:349-362. doi:10.1007/ s00299-013-1535-x

Kwapata K, Nguyen T, Sticklen M (2012) Genetic transformation of common bean (Phaseolus vulgaris L.) with the Gus color marker, the Bar herbicide resistance, and the barley (Hordeum vulgare) HVA1 drought tolerance genes. Int J Agron ID 198960, 8 pps. http://dx.doi.org/10.1155/2012/198960

Larson-Rabin Z, Li Z, Masson PH, Day CD (2009) FZR2/CCS52A1 expression is a determinant of endoreduplication and cell expansion in Arabidopsis. Plant Physiol 149:874-884. doi:10.1104/pp.108. 132449

Le BH, Wagmaister JA, Kawashima T, Bui AQ, Harada JJ, Goldberg RB (2007) Using genomics to study legume seed development. Plant Physiol 144:562-574. doi:10.1104/pp. 107.100362

Lease K, Ingham E, Walker JC (1998) Challenges in understanding RLK function. Curr Op Plant Biol 1:388-392. doi:10.1016/S13695266(98)80261-6

Lee KP, Piskurewicz U, Turecková V, Strnad M, Lopez-Molina L (2010) A seed coat bedding assay shows that RGL2-dependent release of ABA by the endosperm controls embryo growth in Arabidopsis dormant seeds. PNAS 107:19108-19113. doi:10.1073/pnas.1012896107

Lemontey C, Mousset-Declas C, Munier-Jolain N, Boutin JP (2000) Maternal genotype influences pea seed size by controlling both mitotic activity during early embryogenesis and final endoreduplication level/cotyledon cell size in mature seed. J Exp Bot 51:167-175. doi:10.1093/jexbot/51.343.167

Le Signor C, Savois V, Aubert G, Verdier J, Nicolas M, Pagny G, Moussy F, Sanchez M, Baker D, Clarke J, Thompson R (2009) Optimizing TILLING populations for reverse genetics in Medicago truncatula. Plant Biotechnol J 7:430-441. doi:10.1111/j.1467-7652.2009. 00410.x

Li HC, Chuang K, Henderson JT, Rider SD, Bai Y, Zhang H, Fountain M, Gerber J, Ogas J (2005) PICKLE acts during germination to repress expression of embryonic traits. Plant J 44:1010-1022. doi:10.1111/j. 1365-313X.2005.02602.x

Lionneton E, Beuret W, Delaitre C, Ochatt S, Rancillac M (2000) Improved microspore culture and double haploid plant regeneration for the brown condiment mustard (Brassica juncea). Plant Cell Rep 20:126-130. doi:10.1007/s002990000292

Lotan T, Ohto M, Yee KM, West MA, Lo R, Kwong RW, Yamagishi K, Fischer RL, Goldberg RB, Harada JJ (1998) Arabidopsis LEAFY COTYLEDON1 is sufficient to induce embryo development in vegetative cells. Cell 93:1195-1205. doi:10.1016/S0092-8674(00) 81463-4

Lülsdorf MM, Croser JS, Ochatt SO (2011) Androgenesis and doubledhaploid production in food legumes. In: Pratap A, Kumar J (eds) Biology and breeding of food legumes. CAB International, Oxford, pp 159-177, 9781845937669

Lur H, Setter TL (1993) Role of auxin in maize endosperm development. Timing of nuclear DNA endoreduplication, zein expression, and cytokinin. Plant Physiol 103:273-280. doi:10.1104/pp.103.1.273

Mobini SH, Lülsdorf M, Warkentin TD, Vandenberg A (2014) Plant growth regulators improve in vitro flowering and rapid generation advancement in lentil and faba bean. In Vitro Cell Dev Biol Plant. doi:10.1007/s11627-014-9647-8

Mohamed R, Wang CT, Ma C, Shevchenko O, Dye SJ, Puzey JR, Etherington E, Sheng XY, Meilan R, Strauss SH, Brunner AM (2010) Populus CEN/TFL1 regulates first onset of flowering, axillary meristem identity and dormancy release in Populus. Plant J 62: 674-688. doi:10.1111/j.1365-313X.2010.04185.x

Mordhorst AP, Toonen MAJ, DeVries SC (1997) Plant embryogenesis. Crit Rev Plant Sci 16:535-576. doi:10.1080/07352689709701959

Munier-Jolain NG, Ney B (1998) Seed growth rate in grain legumes II. Seed growth rate depends on cotyledon cell number. J Exp Bot 49: 1971-1976. doi:10.1093/jxb/49.329.1971

Nagl W, Jeanjour M, Kling H, Kuhner S, Michels I, Muller T, Stein B (1983) Genome and chromatin organization in higher plants. Biol Zbl 102:129-148

Noguero M, Atif RM, Ochatt S, Thompson RD (2013) The role of the DNA-binding One Zinc Finger (DOF) transcription factor family in plants. Plant Sci 209:32-45. doi:10.1016/j.plantsci.2013.03.016

Ochatt SJ (2006) Flow cytometry. Ploidy determination, cell cycle analysis, DNA content per nucleus. In: Medicago truncatula handbook. http://www.noble.org/medicagohandbook/index.html

Ochatt SJ (2008) Flow cytometry in plant breeding. Cytometry 73A:581598. doi:10.1002/cyto.a.20562

Ochatt SJ (2011) Immature seeds and embryos of Medicago truncatula cultured in vitro. In: Thorpe TA, Yeung EC (eds) Plant embryo culture: methods and protocols; methods in molecular biology, vol. 710. Springer Protocols, Humana Press, New York, pp 39-52. doi: 10.1007/978-1-61737-988-8 4

Ochatt SJ (2013a) Cell morphometry as predictor of protein legume in vitro growth. In: Jain SM, Dutta Gupta S (eds) Biotechnology of neglected and underutilized crops. Springer, Dordrecht, pp 7182. doi:10.1007/978-94-007-5500-0 5

Ochatt SJ (2013b) Plant cell electrophysiology: applications in growth enhancement, somatic hybridization and gene transfer. Biotechnol Adv 31:1237-1246. doi:10.1016/j.biotechadv.2013.03.008

Ochatt S, Moessner A (2010) Rounding up plant cells. Int J Plant Biol 1: 40-42. doi:10.4081/pb.2010.e8

Ochatt SJ, Sangwan RS (2008) In vitro shortening of generation time in Arabidopsis thaliana. Plant Cell Tissue Org Cult 93:133-137. doi: 10.1007/s11240-008-9351-7

Ochatt SJ, Pontécaille C, Rancillac M (2000a) The growth regulators used for bud regeneration and shoot rooting affect the competence for flowering and seed set in regenerated plants of protein pea. In Vitro Cell Dev Biol Plants 36:188-193. doi:10.1007/s11627-000-0035-1

Ochatt S, Mousset-Déclas C, Rancillac M (2000b) Fertile pea plants regenerate from protoplasts when calluses have not undergone endoreduplication. Plant Sci 156:177-183. doi:10.1016/S01689452(00)00250-8

Ochatt SJ, Muneaux E, Machado C, Jacas L, Pontécaille C (2002a) The hyperhydricity of in vitro regenerants of grass pea (Lathyrus sativus 
L.) is linked with an abnormal DNA content. J Plant Physiol 159: 1021-1028. doi:10.1078/0176-1617-00682

Ochatt SJ, Sangwan RS, Marget P, Ndong YA, Rancillac M, Perney P (2002b) New approaches towards the shortening of generation cycles for faster breeding of protein legumes. Plant Breed 121: 436-440. doi:10.1046/j.1439-0523.2002.746803.x

Ochatt S, Muilu R, Ribalta F (2008) Cell morphometry and osmolarity as early indicators of the onset of embryogenesis from cell suspension cultures of grain legumes and model systems. Plant Biosyst 142: 480-486. doi:10.1080/11263500802410827

Ochatt S, Jacas L, Patat-Ochatt EM, Djennane S (2013) Flow cytometric analysis and molecular characterization of Agrobacterium tumefaciens-mediated transformants of Medicago truncatula. Plant Cell Tissue Org Cult 113:237-244. doi:10.1007/s11240012-0263-1

Ochatt S, Pech C, Grewal R, Conreux C, Lulsdorf M, Jacas L (2009) Abiotic stress enhances androgenesis from isolated microspores of some legume species (Fabaceae). J Plant Physiol 166:1314-1328. doi:10.1016/j.jplph.2009.01.011

Ochatt SJ, Sangwan RS (2010) In vitro flowering and seed set: acceleration of generation cycles. In: Davey MR, Anthony P (eds) Plant cell culture: essential methods. Wiley, Chichester, pp 97-110, 978-0470-68648-5

Ochatt SJ, Atif RM, Patat-Ochatt EM, Jacas L, Conreux C (2010) Competence versus recalcitrance for in vitro regeneration. Not Bot Hort Agrobot Cluj 38:102-108

Ochatt SJ, Abirached-Darmency M, Marget P, Aubert G (2007) The Lathyrus Paradox: "poor men's diet" or a remarkable genetic resource for protein legume breeding? In: Ochatt SJ, Jain SM (eds) Breeding of neglected and under-utilised crops, spices and herbs, Science Press, Plymouth, UK, pp 41-60

Parádi I, van Tuinen D, Morandi D, Ochatt S, Franck R, Jacas L, DumasGaudot E (2010) Transcription of two Blue Copper-Binding protein isogenes is highly correlated with arbuscular mycorrhizal development in Medicago truncatula. Mol Plant Microbe Interact 23:11751183. doi:10.1094/MPMI-23-9-1175

Patrick JW, Stoddard FL (2010) Physiology of flowering and grain filling in faba bean. Field Crop Res 115:234-242

Peng W (2011) GM crop cultivation surges, but novel traits languish. Nat Biotechnol 29:302. doi:10.1038/nbt.1842

Pérez-Clemente RM, Gómez-Cadenas A (2012) In vitro tissue culture, a tool for the study and breeding of plants subjected to abiotic stress conditions In: Agricultural and biological sciences "Recent advances in plant in vitro culture", eds Leva A, Rinaldi LMR, ISBN 978-953-51-0787-3, doi: 10.5772/50671

Potrykus I (2013) Unjustified regulation prevents use of GMO technology for public good. Trends Biotechnol 31:131-133. doi:10.1016/j. tibtech.2012.11.008

Qiu Q-S, Guo Y, Dietrich MA, Schumaker KS, Zhu J-K (1999) Regulation of SOS1, a plasma membrane $\mathrm{Na} / \mathrm{H}+$ exchanger in Arabidopsis thaliana, by SOS2 and SOS3. PNAS 99:8436-8441. doi:10.1073/pnas. 122224699

Rahmani F, Hummel M, Schuurmans J, Wiese-Klinkenberg A, Smeekens S, Hanson J (2009) Sucrose control of translation mediated by an upstream open reading frame-encoded peptide. Plant Physiol 150: 1356-1367. doi:10.1104/pp.109.136036

Rai MK, Kaliaa RK, Singh R, Gangola MP, Dhawan AK (2011) Developing stress tolerant plants through in vitro selection-an overview of the recent progress. Environ Exp Bot 71:89-98. doi: 10.1016/j.envexpbot.2010.10.021

Rajjou L, Duval M, Gallardo K, Catusse J, Bally J, Job C, Job D (2012) Seed germination and vigor. Ann Rev Plant Biol 63:3.1-3.27. doi: 10.1146/annurev-arplant-042811-105550

Rech EL, Ochatt SJ, Chand PK, Power JB, Davey MR (1987) Electroenhancement of division of plant protoplast-derived cells. Protoplasma 141:169-176. doi:10.1007/BF01272899
Rech EL, Ochatt SJ, Chand PK, Davey MR, Mulligan BJ, Power JB (1988) Electroporation increases DNA-synthesis in cultured plantprotoplasts. Biotechnology 6:1091-1093. doi:10.1038/nbt09881091

Ribalta F, Croser J, Ochatt S (2012) Flow cytometry enables identification of sporophytic eliciting stress treatments in gametic cells. J Plant Physiol 169:104-110. doi:10.1016/j.jplph.2011.08.013

Ribalta FM, Croser JS, Erskine W, Finnegan PM, Lülsdorf MM, Ochatt SJ (2014) Antigibberellin-induced reduction of internode length favors in vitro flowering and seed-set in different pea genotypes. Biol Plant 58:39-46. doi:10.1007/s10535-0130379-0

Rokhina EV, Lens P, Virkutyte J (2009) Low-frequency ultrasound in biotechnology: state of the art. Trends Biotechnol 27:298-306. doi: 10.1016/j.tibtech.2009.02.001

Rose RJ (2008) Medicago truncatula as a model for understanding plant interactions with other organisms, plant development and stress biology: past, present and future. Funct Plant Biol 35:253. doi:10. 1071/FP07297

Shi H, Quintero FJ, Pardo JM, Zhu JK (2002) The putative plasma membrane $\mathrm{Na}^{+} / \mathrm{H}^{+}$antiporter SOS1 controls long-distance $\mathrm{Na}^{+}$ transport in plants. Plant Cell 14:465-477. doi:10.1105/tpc.010371

Shimotohno A, Umeda M (2007) CDK phosphorylation. In: Inze D ed. Cell cycle control and plant development. Oxford: Blackwell Publ, 114-137. ISBN:978-1-4051-5043-9

Skirycz A, Claeys H, De Bodt S, Oikawa A, Shinoda S, Andriankaja M, Maleux K, Nubia BE, Eloy B, Coppens F, Yoo S-D, Saito K, Inzé D (2011) Pause-and-stop: the effects of osmotic stress on cell proliferation during early leaf development in Arabidopsis and a role for ethylene signaling in cell cycle arrest. Plant Cell 23:1876-1888. doi: 10.1105/tpc. 111.084160

Sorrell DA, Marchbank A, McMahon K, Dickinson JR, Rogers HJ, Francis D (2002) A WEE1 homologue from Arabidopsis thaliana. Planta 215:518-522. doi:10.1007/s00425-002-0815-4

Spadafora ND, Parfitt D, Li S, Bruno L, Vaughan R, BuchananWollaston V, Herbert RJ, Bitonti MB, Doonan J, Albani D, Prinsen E, Francis D, Rogers HJ (2012a) Perturbation of cytokinin and ethylene-signaling pathways explain the strong rooting phenotype exhibited by Arabidopsis expressing the Schizosaccharomyces pombe mitotic inducer, cdc25. BMC Plant Biol 12:45. doi:10.1186/ 1471-2229-12-45

Spadafora N, Perrotta L, Nieuwland J, Albani D, Bitonti MB, Herbert RJ, Doonan JH, Marchbank AM, Siciliano I, Lentz Grønlund A, Francis D, Rogers HJ (2012b) Gene dosage effect of WEE1 on growth and morphogenesis from Arabidopsis hypocotyl explants. Ann Bot 110: 1631-1639. doi:10.1093/aob/mcs223

Stone SL, Kwong LW, Yee KM, Pelletier J, Lepiniec L, Fischer RL, Goldberg RB, Harada JJ (2001) LEAFY COTYLEDON2 encodes a B3 domain transcription factor that induces embryo development. PNAS 98:11806-11811. doi:10.1073/pnas.201413498

Sun Y, Dilkes BP, Zhang C, Dante RA, Carneiro NP, Lowe KS, Jug R, Gordon-Kamm WJ, Larkins BA (1999) Characterization of maize (Zea mays L.) Wee1 and its activity in developing endosperm. PNAS 96:4180-4185. doi:10.1073/pnas.96.7.4180

Teixeira da Silva JA, Dobránszki J (2014) Sonication and ultrasound: impact on plant growth and development. Plant Cell Tissue Organ Cult 117:131-143. doi:10.1007/s11240-014-0429-0

Thompson R, Burstin J, Gallardo K (2009) Post-genomics studies of developmental processes in legume seeds. Plant Physiol 151: 1023-1029. doi:10.1104/pp.109.143966

Touraev A, Vincente O, Herberle-Bors E (1997) Initiation of microspore embryogenesis by stress. Trends Plant Sci 2:297-302. doi:10.1016/ S1360-1385(97)89951-7

Traas J, Hülskamp M, Gendreau E, Höfte H (1998) Endoreduplication and development: Rule without dividing? Curr Opin Plant Biol 1: 498-503. doi:10.1016/S1369-5266(98)80042-3 
Trick HN, Finer JJ (1997) SAAT: sonication-assisted Agrobacteriummediated transformation. Transgenic Res 6:329-336. doi:10.1023/ A:1018470930944

Trick HN, Finer JJ (1998) Sonication-assisted Agrobacterium-mediated transformation of soybean [Glycine max (L.) Merrill] embryogenic suspension culture tissue. Plant Cell Rep 17:482-488. doi:10.1007/ s002990050429

Trinh TH, Ratet P, Kondorosi E et al (1998) Rapid and efficient transformation of diploid Medicago truncatula and Medicago sativa ssp. falcata lines improved in somatic embryogenesis. Plant Cell Rep 17: 345-355. doi:10.1007/s002990050405

Vanneste S, Friml J (2009) Auxin: a trigger for change in plant development. Cell 136:1005-1016. doi:10.1016/j.cell.2009.03.001

Verdier J, Thompson RD (2008) Transcriptional regulation of storage protein synthesis during dicotyledon seed filling. Plant Cell Physiol 49:1263-1271. doi:10.1093/pcp/pcn116

Verdier J, Kakar K, Gallardo K, Le Signor C, Aubert G, Schlereth A, Town CD, Udvardi MK, Thompson R (2008) Gene expression profiling of M. truncatula transcription factors identifies putative regulators of grain legume seed filling. Plant Mol Biol 67:567-580. doi: $10.1007 / \mathrm{s} 11103-008-9320-\mathrm{x}$

Verdier J, Dessaint F, Schneider C, Abirached-Darmency M (2013) A combined histology and transcriptome analysis unravels novel questions on Medicago truncatula seed coat. J Exp Bot 64:459-470. doi: $10.1093 / \mathrm{jxb} / \mathrm{ers} 304$

Voisin A-S, Cazenave A-B, Duc G, Salon C (2013) Pea nodule gradients explain $\mathrm{C}$ nutrition and depressed growth phenotype of hypernodulating mutants. Agron Sustain Dev 33:829-838. doi:10. 1007/s13593-013-0146-9

Wang X, Wang B, Jia Y, Huo D, Duan C (2003a) Effect of sound stimulation on cell cycle of chrysanthemum (Gerbera jamesonii). Colloids Surf B: Biointerfaces 29:103-107. doi:10.1016/S09277765(02)00153-4

Wang X, Wang B, Jia Y, Duan C, Akio S (2003b) Effect of sound wave on the synthesis of nucleic acid and protein in chrysanthemum. Colloids Surf B: Biointerfaces 29:99-102. doi:10.1016/S09277765(02)00152-2

Wang Y, Pijut PM (2013) Isolation and characterization of a TERMINAL FLOWER 1 homolog from Prunus serotina Ehrh. Tree Physiol 33: 855-865. doi:10.1093/treephys/tpt051
Wang Y, Luo JP, Wu HQ, Jin H (2009) Conversion of protocorm-like bodies of Dendrobium huoshanense to shoots: the role of polyamines in relation to the ratio of total cytokinins and indole-3acetic acidindole-3-acetic acid. J Plant Physiol 166:2013-2022. doi:10.1016/j.jplph.2009.06.008

Weber H, Borisjuk L, Wobus U (2005) Molecular physiology of legume seed development. Annu Rev Plant Biol 56:253-279. doi:10.1146/ annurev.arplant.56.032604.144201

Weber H, Heim U, Golombek S, Borisjuk L, Wobus U (1998) Assimilate uptake and the regulation of seed development. Seed Sci Res 8:331346. doi:10.1017/S0960258500004268

Wei M, Yang C-Y, Wei S-H (2012) Enhancement of the differentiation of protocorm-like bodies of Dendrobium officinale to shoots by ultrasound treatment. J Plant Physiol 169:770-774. doi:10.1016/j.jplph. 2012.01.018

West MA, Harada JJ (1993) Embryogenesis in higher plants: an overview. Plant Cell 5:1361-1369. doi:10.1105/tpc.5.10.1361

Wiese A, Elzinga N, Wobbes B, Smeekens S (2004) A conserved upstream open reading frame mediates sucrose-induced repression of translation. Plant Cell 16:1717-1729. doi:10.1105/tpc.019349

Wirsich M, Atif RM, Schroeder M-B, Thompson RD, Ochatt SJ (2013) Unraveling the effect of the transcription factor DOF1147 on the in vitro effect of auxin on cell division and endoreduplication in developing seeds of the model legume Medicago truncatula. Meet German Soc Plant Biotech: Plant Biotechnology-Applications in Breeding and Production (29-30/08/2013, Geisenheim, Germany). Poster

Woodward AW, Bartel B (2005) Auxin: regulation, action, and interaction. Ann Bot 95:707-735. doi:10.1093/aob/mci083

Yu Y, Xue L, Yang L (2014) Winter legumes in rice crop rotations reduces nitrogen loss, and improves rice yield and soil nitrogen supply. Agron Sustain Dev 34:633-640. doi:10.1007/s13593-013-0173-6

Zuber H, Davidian JC, Aimé D, Belghazi M, Wirtz M, Hell R, Thompson R, Gallardo K (2010) The seed composition of Arabidopsis mutants for the group 3 sulphate transporters indicates a role in sulphate translocation within developing seeds. Plant Physiol 154:913-926. doi:10.1104/pp.110.162123

Zuo J, Niu QW, Frugis G, Chua NH (2002) The WUSCHEL gene promotes vegetative-to-embryonic transition in Arabidopsis. Plant J 30:349-359. doi:10.1046/j.1365-313X.2002.01289.x 